\title{
Seasonality of nitrogen sources, cycling, and loading in a New England river discerned from nitrate isotope ratios
}

\author{
Veronica R. Rollinson ${ }^{1}$, Julie Granger ${ }^{1}$, Sydney C. Clark $^{2}$, Mackenzie L. Blanusa ${ }^{1}$, Claudia P. Koerting ${ }^{1}$, \\ Jamie M. P. Vaudrey ${ }^{1}$, Lija A. Treibergs ${ }^{1,4}$, Holly C. Westbrook ${ }^{1,3}$, Catherine M. Matassa ${ }^{1}$, Meredith G. Hastings ${ }^{2}$, \\ and Craig R. Tobias ${ }^{1}$ \\ ${ }^{1}$ Department of Marine Sciences, University of Connecticut, Groton, 06340, USA \\ ${ }^{2}$ Department of Earth, Environmental and Planetary Sciences, Brown University, Providence, 02912, USA \\ ${ }^{3}$ School or the Earth, Ocean and Environment, University of South Carolina, Columbia, 29208, USA \\ ${ }^{4}$ Adirondack Watershed Institute, Paul Smith's College, Paul Smiths, 12970, USA
}

Correspondence: Veronica R. Rollinson (veronica.rollinson@uconn.edu)

Received: 17 October 2020 - Discussion started: 4 November 2020

Revised: 10 February 2021 - Accepted: 11 February 2021 - Published: 10 June 2021

\begin{abstract}
Coastal waters globally are increasingly impacted due to the anthropogenic loading of nitrogen $(\mathrm{N})$ from the watershed. To assess dominant sources contributing to the eutrophication of the Little Narragansett Bay estuary in New England, we carried out an annual study of $\mathrm{N}$ loading from the Pawcatuck River. We conducted weekly monitoring of nutrients and nitrate $\left(\mathrm{NO}_{3}^{-}\right)$isotope ratios $\left({ }^{15} \mathrm{~N} /{ }^{14} \mathrm{~N}\right.$, ${ }^{18} \mathrm{O} /{ }^{16} \mathrm{O}$, and ${ }^{17} \mathrm{O} /{ }^{16} \mathrm{O}$ ) at the mouth of the river and from the larger of two wastewater treatment facilities (WWTFs) along the estuary, as well as seasonal along-river surveys. Our observations reveal a direct relationship between $\mathrm{N}$ loading and the magnitude of river discharge and a consequent seasonality to $\mathrm{N}$ loading into the estuary - rendering loading from the WWTFs and from an industrial site more important at lower river flows during warmer months, comprising $\sim 23 \%$ and $\sim 18 \%$ of $\mathrm{N}$ loading, respectively. Riverine nutrients derived predominantly from deeper groundwater and the industrial point source upriver in summer and from shallower groundwater and surface flow during colder months - wherein $\mathrm{NO}_{3}^{-}$associated with deeper groundwater had higher ${ }^{15} \mathrm{~N} /{ }^{14} \mathrm{~N}$ ratios than shallower groundwater. Corresponding $\mathrm{NO}_{3}^{-}{ }^{18} \mathrm{O} /{ }^{16} \mathrm{O}$ ratios were lower during the warm season, due to increased biological cycling in-river. Uncycled atmospheric $\mathrm{NO}_{3}^{-}$, detected from its unique massindependent $\mathrm{NO}_{3}^{-}{ }^{17} \mathrm{O} /{ }^{16} \mathrm{O}$ vs. ${ }^{18} \mathrm{O} /{ }^{16} \mathrm{O}$ fractionation, accounted for $<3 \%$ of riverine $\mathrm{NO}_{3}^{-}$, even at elevated discharge. Along-river, $\mathrm{NO}_{3}^{-}{ }^{15} \mathrm{~N} /{ }^{14} \mathrm{~N}$ ratios showed a correspondence to regional land use, increasing from agricultural
\end{abstract}

and forested catchments to the more urbanized watershed downriver. The evolution of ${ }^{18} \mathrm{O} /{ }^{16} \mathrm{O}$ isotope ratios alongriver conformed to the notion of nutrient spiraling, reflecting the input of $\mathrm{NO}_{3}^{-}$from the catchment and from in-river nitrification and its coincident removal by biological consumption. These findings stress the importance of considering seasonality of riverine $\mathrm{N}$ sources and loading to mitigate eutrophication in receiving estuaries. Our study further advances a conceptual framework that reconciles with the current theory of riverine nutrient cycling, from which to robustly interpret $\mathrm{NO}_{3}^{-}$isotope ratios to constrain cycling and source partitioning in river systems.

\section{Introduction}

Human activities have resulted in a substantial increase in the delivery of nutrients from terrestrial to aquatic and marine systems (Gruber and Galloway, 2008). In marine systems, increased loading of reactive nitrogen $(\mathrm{N})$ has resulted in coastal eutrophication, engendering the loss of valuable nearshore habitat such as seagrass beds and oyster reefs, depletion of dissolved oxygen (creating so-called "dead zones"), and increased frequency and severity of algal blooms - including toxic brown and red tides causing fish kills (Heisler et al., 2008). In densely populated areas like the northeast United States, excess anthropogenic nitrogen loads originate from wastewater treatment facilities 
(WWTFs), septic systems, industrial discharge, fertilizer applied to turf and agricultural lands, and atmospheric sources from industry and fossil fuel use (Valiela et al., 1997; McClelland et al., 2003; Latimer and Charpentier, 2010). The pervasive degradation of coastal marine ecosystems is alarming and of significant concern to coastal communities worldwide.

The transfer of nutrients from land to the coast is facilitated by rivers, which constitute an effective pipeline that collects nutrients from the watershed, ultimately discharging these to the coast. The mitigation of estuarine eutrophication thus relies on identifying primary sources of nutrients to riverine systems. Nutrients are fundamentally delivered to rivers from non-point sources: from waters entering the river via surface runoff, sub-surface groundwater in the unsaturated zone, and groundwater within the water table. Nutrients also enter rivers from point sources, including WWTFs as well as industrial discharge, which can dominate $\mathrm{N}$ loading in urbanized watersheds (Howarth et al., 1996). The nutrient loads contained in surface and deeper groundwater entering rivers differ markedly depending on land use. In temperate pristine systems, soil and groundwater concentrations are generally low, with reactive $\mathrm{N}$ originating from atmospheric deposition, biological $\mathrm{N}_{2}$ fixation in soils, and $\mathrm{N}$ in rocks and minerals (Hendry et al., 1984; Holloway et al., 1998; Morford et al., 2016). Higher concentrations of reactive $\mathrm{N}$ are found in waters draining agricultural and urbanized areas (Dubrovsky et al., 2010; Baron et al., 2013).

The $\mathrm{N}$ loaded to the watershed is partially attenuated through biological cycling in soils and aquifers. Specifically, organic $\mathrm{N}$ is degraded to reduced $\mathrm{N}$ species that are oxidized (nitrified) to nitrate $\left(\mathrm{NO}_{3}^{-}\right)$in oxygenated zones of groundwater. $\mathrm{NO}_{3}^{-}$is otherwise removed from anoxic groundwater by denitrification, reduced to inert $\mathrm{N}_{2}$. Reactive $\mathrm{N}$ is further cycled and attenuated in-river. The hyporheic zone, where groundwater interchanges with stream and river water, creates a complex environment that can stimulate nitrification and denitrification, as oxic and anoxic pockets exist in close proximity (Sebilo et al., 2003; Harvey et al., 2013). Reactive nitrogen can be further attenuated by benthic denitrification within the river channel (Sebilo et al., 2003; Kennedy et al., 2008; Mulholland et al., 2008).

Identifying sources of $\mathrm{N}$ to rivers can be difficult due to the expanse and heterogeneity of the watershed, the long integration time of deeper groundwater, and the degree of biological $\mathrm{N}$ cycling in groundwater and in-river. While measurements of $\mathrm{N}$ concentrations along the river channel in relation to regional land use can offer insights in this regard, $\mathrm{N}$ sources can be further resolved using complementary measurements of the naturally occurring $\mathrm{N}$ and oxygen $(\mathrm{O})$ isotope ratios of riverine $\mathrm{NO}_{3}^{-}\left({ }^{15} \mathrm{~N} /{ }^{14} \mathrm{~N}\right.$ and ${ }^{18} \mathrm{O} /{ }^{16} \mathrm{O}$, respectively). Henceforth, we express the isotope ratios in delta no- tation:

$\delta(\% o)=\left(\frac{\text { isotope ratio of sample }}{\text { isotope ratio of reference }}-1\right) \times 1000$.

The reference for $\delta^{15} \mathrm{~N}$ is $\mathrm{N}_{2}$ in air and for $\delta^{18} \mathrm{O}$ is Vienna Standard Mean Ocean Water (VSMOW). The N and O isotope ratios of $\mathrm{NO}_{3}^{-}$provide constraints on $\mathrm{N}$ sources and cycling in part because respective $\mathrm{N}$ sources cover discrete ranges of $\delta^{15} \mathrm{~N}$ and $\delta^{18} \mathrm{O}$ values (Kendall et al., 2007). Reactive $\mathrm{N}$ species from atmospheric deposition, biological $\mathrm{N}_{2}$ fixation, and industrial $\mathrm{N}_{2}$ fixation share overlapping ranges of $\delta^{15} \mathrm{~N}$ values $(\leq 0 \%$ ), which differ appreciably from those of livestock and human waste (8\%o-25\%; Kendall, 1998; Böhlke, 2003; Xue et al., 2009). In contrast, the $\delta^{18} \mathrm{O}$ signatures of atmospheric $\mathrm{NO}_{3}^{-}(60 \%$ o-80\%o) are distinct from those of industrial $\mathrm{NO}_{3}^{-}(\sim 25 \%)$ and from $\mathrm{NO}_{3}^{-}$produced by nitrification, which aligns closely with that of ambient water (Boshers et al., 2019, and references therein). Atmospheric $\mathrm{NO}_{3}^{-}$is further distinguished by a mass-independent $\delta^{17} \mathrm{O}$ vs. $\delta^{18} \mathrm{O}$ fractionation that is not manifest in industrial and biological $\mathrm{NO}_{3}^{-}$(Savarino and Thiemens, 1999).

The isotope ratios of $\mathrm{NO}_{3}^{-}$also provide constraints on $\mathrm{N}$ cycling because $\mathrm{N}$ and $\mathrm{O}$ isotopologues are differentially sensitive to respective biological $\mathrm{N}$ transformations (reviewed by Casciotti, 2016), implicating different mass balance considerations within the $\mathrm{N}$ cycle that permit differentiation of $\mathrm{N}$ sources from cycling. Briefly, in riverine systems where $\mathrm{NO}_{3}^{-}$is the dominant $\mathrm{N}$ pool, $\delta^{15} \mathrm{~N}_{\mathrm{NO}_{3}}$ integrates across values of reactive $\mathrm{N}$ delivered from the watershed, minus $\mathrm{NO}_{3}^{-}$ removed by benthic denitrification (if associated with $\mathrm{N}$ isotopic fractionation; Sebilo et al., 2003). Values of $\delta^{15} \mathrm{~N}_{\mathrm{NO}_{3}}$ are additionally sensitive to isotopic fractionation due to internal cycling in-river - assimilation and remineralization to $\mathrm{NO}_{3}^{-}$via nitrification - in systems where riverine $\mathrm{N}$ is otherwise partitioned comparably between oxidized and reduced pools (i.e., $\mathrm{NO}_{3}^{-}$vs. ammonium and particulate N; Sebilo et al., 2006). Riverine $\delta^{18} \mathrm{O}_{\mathrm{NO}_{3}}$, in turn, integrates across values of exogenous $\mathrm{NO}_{3}^{-}$delivered to the river from the watershed and from atmospheric deposition, those of $\mathrm{NO}_{3}^{-}$produced in-river by nitrification, minus the $\mathrm{NO}_{3}^{-}$lost concurrently to denitrification and assimilation (see Sigman and Fripiat, 2019). Interpreted in tandem, $\mathrm{NO}_{3}^{-} \mathrm{N}$ and $\mathrm{O}$ isotopologue ratios thus offer complementary constraints to identify important source terms and characterize cycling.

Here we present a study of annual N loading from the Pawcatuck River to the Little Narragansett Bay in southern New England (USA), wherein we exploit measurements of the $\mathrm{N}$ and $\mathrm{O}$ isotope ratios of riverine $\mathrm{NO}_{3}^{-}$to draw inferences on dominant $\mathrm{N}$ sources from the watershed and on riverine $\mathrm{N}$ cycling. The site is heavily impacted by nitrogen loading as evidenced by the history of the habitat: vast seagrass beds of Zostera marina (eelgrass) historically established in Little Narragansett Bay were overtaken in the early 1990s by extensive mats of filamentous macroalgae dominated by the Cladophoraceae clade, whose substantial biomass has been 
linked to frequent events of nighttime hypoxia in the bay's shallow-water coves (Dodds and Gudder, 1992; Dillingham et al., 1993; D'Avanzo and Kremer, 1994; Tiner et al., 2003; Berezina and Golubkov, 2008; National Water Quality Monitoring Council, 2020). The evident eutrophication of the estuary has raised questions regarding the magnitude of $\mathrm{N}$ loading from the Pawcatuck River and from the local WWTFs, whose respective contributions must be assessed in order to devise targets for mitigation. To this end, we conducted weekly monitoring of nutrients and $\mathrm{NO}_{3}^{-}$isotopologue ratios at the mouth of the Pawcatuck River and of nutrients discharged from the larger of two WWTFs along the estuary, as well as parallel measurements of samples collected from seasonal along-river surveys. Utilizing $\mathrm{NO}_{3}^{-}$isotopologue ratios to identify $\mathrm{N}$ sources has immediate local implications for management of the watershed, allows for extrapolation to similar watersheds throughout the temperate zone, and most importantly isolates the seasonal and flow-dependent nature of $\mathrm{N}$ cycling within a riverine system transitioning to an estuarine system. This last finding has direct relevance to water quality modeling efforts in temperate estuaries.

\section{Methods}

\subsection{Site description}

The Pawcatuck River watershed $\left(\sim 760 \mathrm{~km}^{2}\right)$ is located predominantly in the state of Rhode Island (RI) with a small portion in eastern Connecticut (Fig. 1). The river originates at Worden Pond in Wakefield, RI, and extends $47 \mathrm{~km}$ southwest to Westerly, RI. It is joined by the Wood River, which originates in northern RI and runs $29 \mathrm{~km}$ south to Wood River Junction. The drainage basin is mostly flat, hosting terrain with forests and wetlands $(73 \%)$ and relatively low human population ( $~ 56400$; based on a dasymetric analysis of the 2010 US Census Bureau population data in the watershed; Vaudrey et al., 2017) - owing in part to state land trust holdings that protect $\sim 22 \%$ of the watershed in RI from development (Dillingham et al., 1992; US Geological Survey, 2011). Agricultural areas comprise $8 \%$ of land use (US Geological Survey, 2011) and are mostly located in the upper watershed, which hosts a number of turf farms. In 2005, Washington county - where the Pawcatuck River originates - was noted as having the highest density of turf farms in the United States (US Environmental Protection Agency, 2005). Urbanized and developed land usage comprises $13 \%$ of the total watershed with the majority of the urban areas concentrated on the lower $19 \mathrm{~km}$ portion of the river, between Bradford and Westerly (US Geological Survey, 2011).

Three nutrient discharge permits are allotted along the river by the RI Department of Environmental Management (RI DEM; Fig. 1): Kenyon Industries, a fabric processing plant, is located approximately $7 \mathrm{~km}$ downstream from Worden Pond. Two WWTFs discharge into the estuary and are located $1 \mathrm{~km}$ downstream of the Westerly Bridge, approximately $47 \mathrm{~km}$ downstream of Worden Pond.

\subsection{Sample collection}

We conducted four distinct sampling regimens: (a) weekly river samplings at the mouth of the river, (b) weekly WWTF effluent samplings, (c) seasonal along-river surveys, and (d) rainwater samplings. We collected weekly river samples (a) from 10 January 2018 through to 12 January 2019 at two sites: the Stillman Bridge near the mouth of the freshwater portion of the river and $\sim 1 \mathrm{~km}$ downstream at the Westerly Bridge, which marks the limit of seawater intrusion (Figs. 1, S1). (b) We obtained samples of wastewater treatment effluent collected weekly at the Westerly Wastewater Treatment Facility (W-WWTF) from 6 June 2018 to 22 May 2019. (c) We conducted three seasonal along-river surveys on 21 May, 9 November 2018, and 12 March 2019 at 15 discrete sampling stations between Worden Pond and the Westerly Bridge. Additionally, we performed a highly resolved sampling (approximately every $0.75 \mathrm{~km}$ ) of the lower river from Potter Hill Dam (Station 11) to Westerly (Station 15) aboard kayaks in May 2017 (Fig. 1). No samples were collected directly from the retention ponds or their outflow at Kenyon Industries (Fig. 1). (d) We collected rainwater samples following rain events from a rooftop collector at the Avery Point campus in Groton, CT (approximately $18 \mathrm{~km}$ west of the Pawcatuck River), from 6 September to 2 December 2018 , in order to define regional $\mathrm{NO}_{3}^{-}$isotopic endmembers.

Weekly samplings at the Stillman and Westerly bridges occurred around sunrise, before the onset of photosynthetic activity, whereas along-river samples were collected sequentially from sunrise to midday. During each sample collection, river temperature and dissolved oxygen concentrations were measured in situ with a Thermo Orion Star A123 portable dissolved oxygen meter. At each site, river water was collected at $\sim 0.5 \mathrm{~m}$ depth with a Van Dorn bottle and transferred into a $5 \mathrm{~L}$ carboy for transport, on ice, back to the laboratory for processing. In the laboratory, the conductivity of each sample was measured with an Oakton CON 450 conductivity meter. Sub-samples for analyses of dissolved nutrient and $\mathrm{NO}_{3}^{-}$isotope ratios were filtered through precombusted $25 \mathrm{~mm} \mathrm{GF} / \mathrm{F}$ glass fiber filters and collected in acid-washed polypropylene bottles, then stored at $-20^{\circ} \mathrm{C}$ pending analysis. The filters were placed in pre-combusted aluminum foil and frozen at $-20^{\circ} \mathrm{C}$ in preparation for particulate nitrogen isotope ratio analyses. Samples for chlorophyll $a$ analysis were similarly collected onto $25 \mathrm{~mm} \mathrm{GF} / \mathrm{F}$ filters.

The weekly effluent samples at the Westerly WWTF were collected by facility personnel into $0.5 \mathrm{~L}$ acid-washed polypropylene bottles and frozen pending monthly pick-ups by our team. Two types of samples were collected on a weekly basis: grab and composite samples. Grab samples 

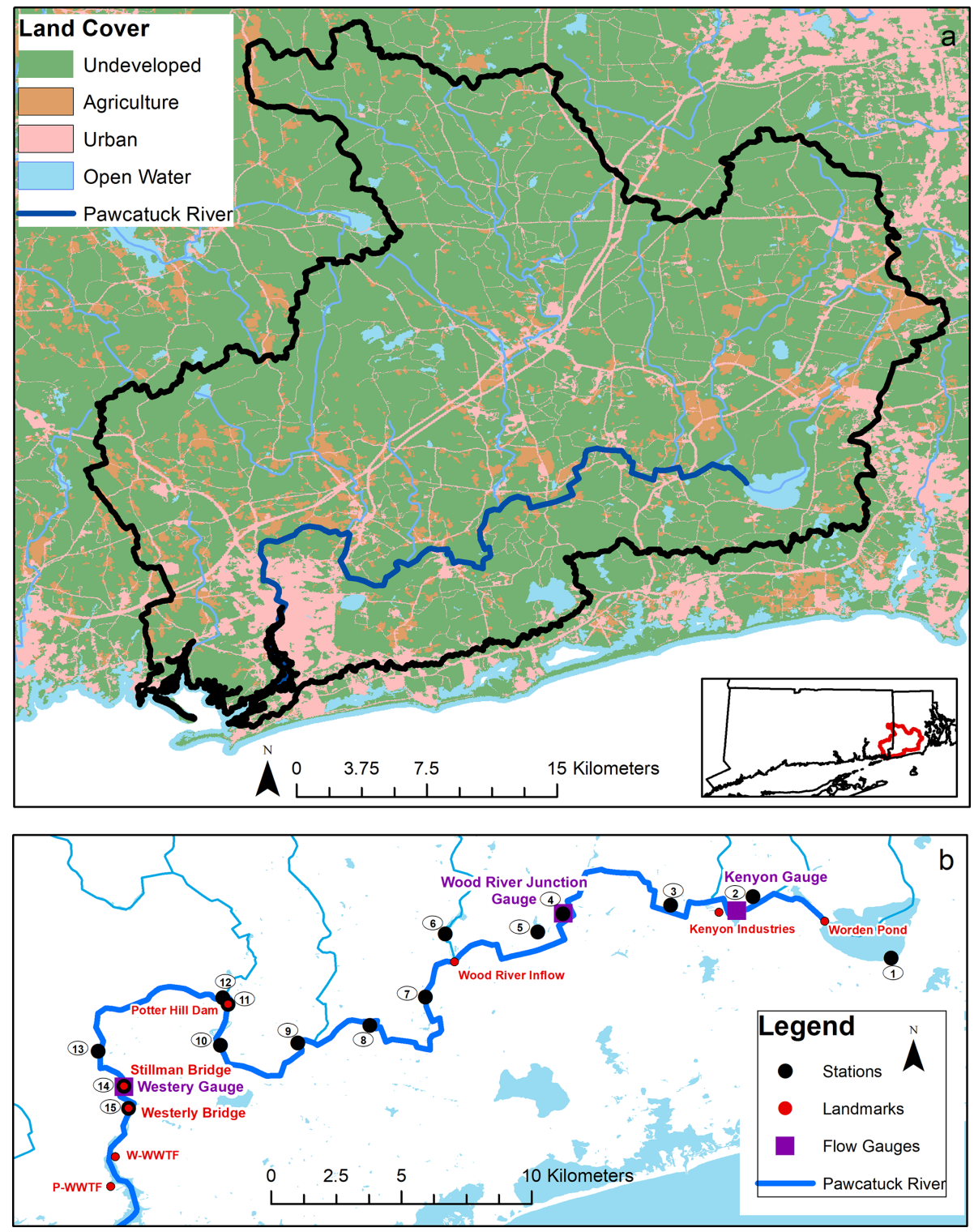

Figure 1. (a) Map of the Pawcatuck River watershed and associated land use (URIEDC_RIGIS, 2019; US Geological Survey, 2011). (b) Map of sampling locations, landmarks including the Westerly and Pawcatuck wastewater treatment facilities (WWTFs), and river discharge gauges along the Pawcatuck River (US Geological Survey, 2005; US Census Bureau, 2017).

correspond to treated effluent collected prior to its release to the river, while composite samples are effluent collected continually over a $24 \mathrm{~h}$ period, thus providing a concentrationweighted daily average. In the laboratory, samples for nutrient analysis were thawed and filtered through a $25 \mathrm{~mm} \mathrm{GF} / \mathrm{F}$ filter and frozen at $-20^{\circ} \mathrm{C}$ pending analysis. Samples for particulate $\mathrm{N}$ analysis were not collected from the WWTF.

Rainwater samples were collected into trace-metal-clean $1 \mathrm{~L}$ Teflon bottles outfitted with a glass funnel to create a vapor lock preventing evaporation. These samples were stored unfiltered at $-20^{\circ} \mathrm{C}$ pending nutrient and $\mathrm{NO}_{3}^{-}$isotope ratio analyses.

\subsection{Nutrient analyses}

The $\mathrm{NO}_{3}^{-}$concentration, $\left[\mathrm{NO}_{3}^{-}\right]$, in river and WWTF samples was measured by conversion to nitric oxide in a hot Vanadium(III) solution followed by detection on a chemiluminescent $\mathrm{NO}_{x}$ analyzer (Teledyne ${ }^{\mathrm{TM}}$; Braman and Hendrix, 1989). Incident nitrite in the samples was first reacted with Griess reagents (Strickland and Parsons, 1972) before injection into the hot Vanadium(III) solution in order to detect $\mathrm{NO}_{3}^{-}$only. The concentration of nitrite, $\left[\mathrm{NO}_{2}^{-}\right]$, in river samples was measured by conversion to nitric oxide in hot iodine solution, followed by detection on the chemiluminescent $\mathrm{NO}_{x}$ analyzer (Garside, 1982). For the 
rainwater samples, $\left[\mathrm{NO}_{3}^{-}\right]$and $\left[\mathrm{NO}_{2}^{-}\right]$were measured on a SmartChem discrete nutrient autoanalyzer (Unity Scientific $^{\mathrm{TM}}$ ) using standard protocols adapted for the SmartChem instrument (Strickland and Parsons, 1972; US Environmental Protection Agency, 1993b; 4500- $\mathrm{NO}_{2}^{-}, 2018 ; 4500-\mathrm{NO}_{3}^{-}$, 2018). Concentrations of ammonium, $\left[\mathrm{NH}_{4}^{+}\right]$, and phosphate, $\left[\mathrm{PO}_{4}^{3-}\right]$, in river and WWTF samples were measured on a SmartChem autoanalyzer using standard protocols (Murphy and Riley, 1962; Strickland and Parsons, 1972; US Environmental Protection Agency, 1978, 1993a; 4500- $\mathrm{NH}_{3}$, 2018; 4500-P, 2018).

The concentration of total dissolved nitrogen, [TDN], in filtered river and WWTF samples was measured by persulfate oxidation to $\mathrm{NO}_{3}^{-}$and then measured via a chemiluminescent $\mathrm{NO}_{x}$ analyzer as described above (Sólorzano and Sharp, 1980; Knapp et al., 2005). The persulfate reagent was first recrystallized following protocol by Grasshoff et al. (1999). A ratio of sample to reagent of 5 to 10 was used in the oxidations. Reagent blanks accounted for $\leq 0.3 \%$ of the TDN signal. The concentration of dissolved organic nitrogen, [DON] was calculated as the difference between [TDN] and dissolved inorganic nitrogen, [DIN], where $[\mathrm{DIN}]=\left[\mathrm{NO}_{3}^{-}\right]+\left[\mathrm{NO}_{2}^{-}\right]+\left[\mathrm{NH}_{4}^{+}\right]$.

\subsection{Chlorophyll $a$ analyses}

Chlorophyll $a$ was extracted from duplicate $25 \mathrm{~mm}$ GF/F filter samples in $5 \mathrm{~mL}$ of $90 \%$ acetone, incubated overnight at $-20^{\circ} \mathrm{C}$, and quantified by fluorescence detection on a Turner Designs Trilogy laboratory fluorometer (Arar and Collins, 1997).

\section{$2.5 \mathrm{NO}_{3}^{-}$isotope ratio analyses}

The nitrogen and oxygen isotope ratios of $\mathrm{NO}_{3}^{-},{ }^{15} \mathrm{~N} /{ }^{14} \mathrm{~N}$, ${ }^{18} \mathrm{O} /{ }^{16} \mathrm{O}$, and ${ }^{17} \mathrm{O} /{ }^{16} \mathrm{O}$ were analyzed using the denitrifier method in samples where $\left[\mathrm{NO}_{3}^{-}\right] \geq 1.5 \mu \mathrm{M}$ (Sigman et al., 2001; Casciotti et al., 2002; Kaiser et al., 2007). Briefly, $\mathrm{NO}_{3}^{-}$was converted quantitatively to a nitrous oxide $\left(\mathrm{N}_{2} \mathrm{O}\right)$ analyte by denitrifying bacteria that lack a terminal reductase (Pseudomonas chlororaphis f. sp. aureofaciens; ATCC $^{\circledR} 13985^{\mathrm{TM}}$ ), followed by analysis of the $\mathrm{N}_{2} \mathrm{O}$ product at the University of Connecticut on a Thermo Delta V gas chromatograph-isotope ration mass spectrometer (GCIRMS) prefaced with a custom-modified Gas Bench II device with two cold traps and a PAL autosampler (Casciotti et al., 2002). The $\mathrm{NO}_{3}^{-}{ }^{17} \mathrm{O} /{ }^{16} \mathrm{O}$ in rainwater (as well as ${ }^{18} \mathrm{O} /{ }^{16} \mathrm{O}$ ) was similarly analyzed by bacterial conversion to $\mathrm{N}_{2} \mathrm{O}$, followed by pyrolysis in a gold tube to $\mathrm{N}_{2}$ and $\mathrm{O}_{2}$ and analysis on a Thermo Delta V GC-IRMS at Brown University (Kaiser et al., 2007).

Coupled $\delta^{15} \mathrm{~N}_{\mathrm{NO}_{3}}$ and $\delta^{18} \mathrm{O}_{\mathrm{NO}_{3}}$ analyses at UConn and Brown University were calibrated from parallel analyses of $\mathrm{NO}_{3}^{-}$reference materials USGS-34 $\left(\delta^{15} \mathrm{~N}:-1.8 \%\right.$ vs. air; $\delta^{18} \mathrm{O}:-27.9 \%$ vs. VSMOW) and IAEA-N3 $\left(\delta^{15} \mathrm{~N}:+4.7 \%\right.$ \% vs. air; $\delta^{18} \mathrm{O}:+25.6 \%$ vs. VSMOW). Samples were analyzed in triplicate among two or more batch analyses. Reproducibility averaged $0.2 \%$ for $\delta^{15} \mathrm{~N}_{\mathrm{NO}_{3}}$ and $0.3 \%$ for $\delta^{18} \mathrm{O}_{\mathrm{NO}_{3}}$. Coupled analyses of $\delta^{18} \mathrm{O}_{\mathrm{NO}_{3}}$ and $\delta^{17} \mathrm{O}_{\mathrm{NO}_{3}}$ of rainwater $\mathrm{NO}_{3}^{-}$and some of the river samples were calibrated with USGS-34 $\left(\Delta^{17} \mathrm{O}\right.$ : $-0.1 \%$ vs. VSMOW) and USGS-35 $\left(\delta^{18} \mathrm{O}+57.5 \%\right.$ vs. VSMOW; $\Delta^{17} \mathrm{O}:+21.6 \%$ vs. VSMOW). The mass-independent fractionation of $\mathrm{NO}_{3}^{-}$ ${ }^{17} \mathrm{O}$ vs. ${ }^{18} \mathrm{O}\left(\Delta^{17} \mathrm{O}\right.$ vs. VSMOW) is calculated from Thiemens (1999):

$\Delta^{17} \mathrm{O}=\delta^{17} \mathrm{O}-0.52 \times \delta^{18} \mathrm{O}$.

The analytical reproducibility for $\Delta^{17} \mathrm{O}_{\mathrm{NO}_{3}}$ averaged $0.3 \%$ o based upon the pooled standard deviation of repeated measures of reference materials. The fraction $(\%)$ of atmospheric $\mathrm{NO}_{3}^{-}$in river water was derived from a two-end-member mixing equation of river water $\mathrm{NO}_{3}^{-}\left(\Delta^{17} \mathrm{O}=0\right)$ with the corresponding atmospheric $\mathrm{NO}_{3}^{-} \Delta^{17} \mathrm{O}$ value $(19.7 \%$ o to $27.2 \%$; Sect. S1), with an associated uncertainty of $\sim 1 \%$ based on the pooled standard deviations of Monte Carlo error propagations.

\subsection{Particulate nitrogen analyses}

Particulate nitrogen $(\mathrm{PN})$ in river samples was collected on pre-combusted $25 \mathrm{~mm} \mathrm{GF/F}$ glass fiber filters that were freeze-dried and then compacted into tin capsules for analysis on a Costech elemental analyzer connected to a Thermo Delta V isotope ratio mass spectrometer via a Conflow IV interface. Samples were calibrated with aliquots of recognized reference materials USGS 40 and $41\left(\delta^{15} \mathrm{~N}=-4.52 \% o\right.$ and $+47.57 \%$ ov. air, respectively), achieving an analytical precision of $\sim 0.3 \%$.

\subsection{Nutrient flux estimates}

Instantaneous nutrient fluxes were estimated from the product of the nutrient concentration and the corresponding mean daily river discharge recorded by USGS gauges, or discharge reported by the Westerly WWTF. Given the large number of available river flow data from the USGS gauge at the Stillman Bridge and effluent discharge from the WWTF in relation to comparatively fewer concentration data, annual fluxes $(L)$ of respective constituents were calculated using Beale's ratio estimator (Beale, 1962; Quiblé et al., 2006), which includes a bias correction factor (the term in parentheses) to account for the covariance between load and river flow values (Eq. 3):

$$
\begin{aligned}
& L=\overline{C Q} \frac{\mu_{q}}{\bar{Q}} n\left(\frac{1+\frac{1}{n_{d}} \frac{S_{C Q}}{\overline{C Q} \cdot \bar{Q}}}{1+\frac{1}{n_{d}} \frac{S_{Q^{2}}}{\bar{Q}^{2}}}\right), \\
& S_{C Q}=\frac{1}{n_{d}-1}\left(\sum_{i=1}^{n_{d}} C_{i} Q_{i}-n_{d} \overline{Q C Q}\right),
\end{aligned}
$$


$S_{Q^{2}}=\frac{1}{n_{d}-1}\left(\sum_{i=1}^{n_{d}} Q_{i}-n_{d} \bar{Q}^{2}\right)$

The term $\mu_{q}$ is the mean of all river discharge measurements, $C_{i}$ the concentration on day $i, Q_{i}$ the average river discharge on day $i, n$ the total number of days for the period of load estimation, and $n_{d}$ the number of observations of $C_{i}$. Overbars denote sample arithmetic means. We further conducted bootstrap analyses to provide estimates of the uncertainty of the respective fluxes.

\section{Results}

\subsection{Weekly river samplings}

The concentration of $\mathrm{NO}_{3}^{-}$measured in samples collected weekly at the Stillman Bridge was lowest in winter and highest in the summer months, ranging from to $9.7 \mu \mathrm{M}$ to as high as $73.5 \mu \mathrm{M}$, with a median value of $30.4 \mu \mathrm{M}$ (Fig. 2a). Comparable concentrations were detected at the Westerly Bridge at each sampling, except for instances where the site experienced saltwater intrusions, evidenced by elevated conductivities (data not shown) - at which times $\left[\mathrm{NO}_{3}^{-}\right]$at the Westerly Bridge was lower due to lower concentrations in the seawater end-member. The concentration of $\mathrm{NO}_{2}^{-}$was negligible in all samples. At both bridge sites, $\left[\mathrm{NO}_{3}^{-}\right]$decreased with increasing river discharge (Fig. 2b; Table 1). The $\left[\mathrm{NO}_{3}^{-}\right]$at the Stillman Bridge, upstream of potential seawater intrusion, also correlated directly with conductivity (Fig. 3a). Values of $\delta^{15} \mathrm{~N}_{\mathrm{NO}_{3}}$ were lowest in winter and increased in summer, ranging from $5.3 \%$ to $9.4 \%$ - thus decreasing with increasing river discharge (Fig. 2c-d; Table 1). Values of $\delta^{18} \mathrm{O}_{\mathrm{NO}_{3}}$ followed a contrasting trend, being lower during the summer months and increasing in winter months, with values ranging from $1.6 \%$ to $6.8 \%$, notwithstanding a single outlying value of $8.1 \%$ (Fig. 2e). Values of $\delta^{18} \mathrm{O}_{\mathrm{NO}_{3}}$ at the bridges increased directly with discharge (Fig. 2f; Table 1). Measurements of $\Delta^{17} \mathrm{O}_{\mathrm{NO}_{3}}$ at the Stillman Bridge ranged from $-0.5 \%$ to $1.9 \%$. The fraction of atmospheric $\mathrm{NO}_{3}^{-}$estimated based on the $\Delta^{17} \mathrm{O}_{\mathrm{NO}_{3}}$ values of precipitation recorded at Avery Point (Sect. S1; Fig. S2) indicated that uncycled atmospheric $\mathrm{NO}_{3}^{-}$was not detected in the majority of the river samples analyzed, with only 10 of 41 samples showing values above our lower limit of detection of $\sim 1 \%$ atmospheric $\mathrm{NO}_{3}^{-}$. The fraction of atmospheric $\mathrm{NO}_{3}^{-}$was otherwise $<3 \%$, notwithstanding a single sample in which atmospheric $\mathrm{NO}_{3}^{-}$accounted for $\sim 7 \%$ of total riverine $\mathrm{NO}_{3}^{-}$ (Fig. 2g). Values of $\Delta^{17} \mathrm{O}_{\mathrm{NO}_{3}}$ nevertheless correlated with river discharge (Fig. 2h; Table 1).

The concentration of $\mathrm{NH}_{4}^{+}$recorded weekly at the bridges was consistently lower than corresponding $\left[\mathrm{NO}_{3}^{-}\right]$. In contrast to $\left[\mathrm{NO}_{3}^{-}\right],\left[\mathrm{NH}_{4}^{+}\right]$at the bridges was lowest in summer and higher in winter, ranging from below detection to $7.8 \mu \mathrm{M}$, and correlated directly with discharge (Fig. $2 \mathrm{i}-\mathrm{j}$ ). The $\left[\mathrm{PO}_{4}^{3-}\right]$ ranged from 0.1 to $2.7 \mu \mathrm{M}$ with one sample as
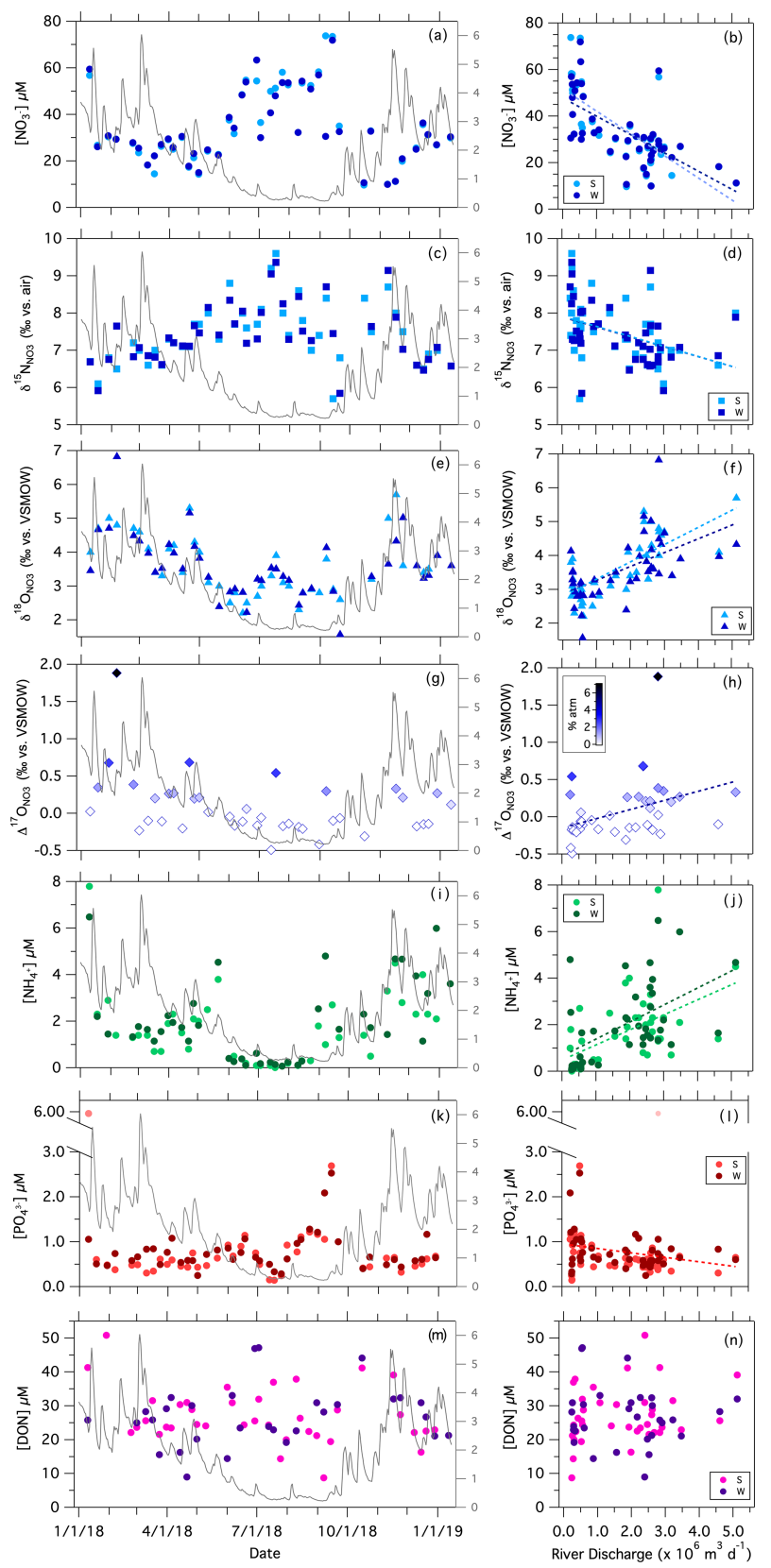

Figure 2. Weekly measurements of solute concentrations and $\mathrm{NO}_{3}^{-}$ isotopologue ratios at the Stillman and Westerly bridges vs. the sampling date (superposed onto river discharge) and vs. the mean daily river discharge recorded at the Stillman Bridge. The secondary axis in the left-hand panels is the river discharge $\left(\times 10^{6} \mathrm{~m}^{3} \mathrm{~d}^{-1}\right)$. $\left[\mathrm{NO}_{3}^{-}\right]$ vs. (a) sampling date and (b) discharge; $\delta^{15} \mathrm{~N}_{\mathrm{NO}_{3}}$ vs. (c) sampling date and (d) discharge; $\delta^{18} \mathrm{O}_{\mathrm{NO}_{3}}$ vs. (e) sampling date and (f) discharge; $\Delta^{17} \mathrm{O}_{\mathrm{NO}_{3}}$ vs. (g) sampling date and (h) discharge; $\left[\mathrm{NH}_{4}^{+}\right]$ vs. (i) sampling date; (j) $\left[\mathrm{NH}_{4}^{+}\right]$vs. discharge; $\left[\mathrm{PO}_{4}^{3-}\right]$ vs. (k) sampling date and (l) discharge; [DON] vs. (m) sampling date and (n) $[\mathrm{DON}]$ vs. discharge. Statistical fits of least-square linear regressions are reported in Table 1. 
Table 1. Correlation coefficients, corresponding intercepts, coefficients of determination $\left(r^{2}\right)$, and statistical probability of least-squared regression analyses from property-property plots of riverine solutes and fluxes. Statistically significant relationships are signaled by an asterisk ( $p$ value $\left.\leq 0.05^{*} ; \leq 0.01^{* *}\right)$.

\begin{tabular}{|c|c|c|c|c|c|c|}
\hline$x$ & $y$ & Location & Slope & Intercept & $r^{2}$ & $p$ value \\
\hline \multirow{23}{*}{$\begin{array}{l}\text { River } \\
\text { discharge } \\
\left(\times 10^{6} \mathrm{~m}^{3} \mathrm{~d}^{-1}\right)\end{array}$} & \multirow{2}{*}[\mathrm{NO}_{3}^{-}]{$(\mu \mathrm{M})$} & $\mathrm{S}$ & -9.1 & 50.6 & 0.50 & \multirow{2}{*}{$\begin{array}{l}* * \\
* *\end{array}$} \\
\hline & & $\mathrm{W}$ & -7.9 & 47.8 & 0.44 & \\
\hline & \multirow{2}{*}{$\delta^{15} \mathrm{~N}_{\mathrm{NO}_{3}}(\% \circ)$} & S & -0.3 & 7.9 & 0.16 & $* *$ \\
\hline & & W & -0.3 & 7.9 & 0.15 & $* *$ \\
\hline & \multirow{2}{*}{$\delta^{18} \mathrm{O}_{\mathrm{NO}_{3}}(\% \circ)$} & $S$ & 0.5 & 2.7 & 0.34 & $* *$ \\
\hline & & W & 0.4 & 2.9 & 0.31 & ** \\
\hline & $\Delta^{17} \mathrm{O}_{\mathrm{NO}_{3}}(\% \circ)$ & $S$ & 0.1 & -0.1 & 0.15 & * \\
\hline & \multirow{2}{*}[\mathrm{NH}_{4}^{+}]{$(\mu \mathrm{M})$} & $\mathrm{S}$ & 0.6 & 0.5 & 0.27 & $* *$ \\
\hline & & $\mathrm{W}$ & 0.7 & 0.6 & 0.29 & ** \\
\hline & \multirow{2}{*}[\mathrm{PO}_{4}^{3-}]{$(\mu \mathrm{M})$} & S & 0.0 & 0.8 & 0.00 & 0.78 \\
\hline & & W & -0.1 & 1.0 & 0.09 & * \\
\hline & \multirow[t]{2}{*}[\mathrm{DON}]{$(\mu \mathrm{M})$} & S & -0.2 & 34.2 & 0.15 & 0.12 \\
\hline & & W & -0.3 & 33.7 & 0.08 & 0.10 \\
\hline & \multirow[t]{2}{*}[\mathrm{PN}]{$(\mu \mathrm{M})$} & $\mathrm{S}$ & 0.4 & 2.4 & 0.09 & 0.07 \\
\hline & & W & 0.3 & 2.8 & 0.06 & 0.18 \\
\hline & \multirow[t]{2}{*}[\operatorname{chl}a]{$\left(\mu \mathrm{g} \mathrm{L}^{-1}\right)$} & S & -0.3 & 3.7 & 0.01 & 0.64 \\
\hline & & W & -0.5 & 4.7 & 0.03 & 0.45 \\
\hline & \multirow[t]{2}{*}{ DIN flux $\left(\mathrm{mold}^{-1}\right)$} & S & $2.6 \times 10^{4}$ & Forced zero & 0.85 & ** \\
\hline & & $\mathrm{W}$ & $2.7 \times 10^{4}$ & Forced zero & 0.86 & $* *$ \\
\hline & \multirow[t]{2}{*}{ DON flux $\left(\mathrm{mol} \mathrm{d}^{-1}\right)$} & $\mathrm{S}$ & $3.0 \times 10^{4}$ & Forced zero & 0.91 & $* *$ \\
\hline & & $\mathrm{W}$ & $2.7 \times 10^{4}$ & Forced zero & 0.94 & $* *$ \\
\hline & \multirow[t]{2}{*}{$\mathrm{TN}$ flux $\left(\mathrm{mold}^{-1}\right)$} & S & $6.0 \times 10^{4}$ & Forced zero & 0.93 & $* *$ \\
\hline & & $\mathrm{W}$ & $6.0 \times 10^{4}$ & Forced zero & 0.95 & $* *$ \\
\hline \multirow[t]{2}{*}[\mathrm{DIN}]{$(\mu \mathrm{M})$} & \multirow[t]{2}{*}[\mathrm{DON}]{$(\mu \mathrm{M})$} & $\mathrm{S}$ & -0.2 & 34.0 & 0.17 & ** \\
\hline & & $\mathrm{W}$ & -0.3 & 33.7 & 0.08 & 0.10 \\
\hline \multirow{11}{*}{$\begin{array}{l}\text { W-WWTF } \\
\text { discharge } \\
\left(\times 10^{4} \mathrm{~m}^{3} \mathrm{~d}^{-1}\right)\end{array}$} & \multirow[t]{3}{*}[\mathrm{NO}_{3}^{-}]{$(\mu \mathrm{M})$} & WWTF comp & -268 & 514 & 0.43 & ** \\
\hline & & WWTF comp-r & -240 & 439 & 0.31 & $* *$ \\
\hline & & WWTF grab & -268 & 544 & 0.42 & ** \\
\hline & \multirow[t]{3}{*}[\mathrm{NH}_{4}^{+}]{$(\mu \mathrm{M})$} & WWTF comp & 232 & -83 & 0.09 & 0.10 \\
\hline & & WWTF comp-r & 449 & -256 & 0.26 & ** \\
\hline & & WWTF grab & 141 & -75 & 0.15 & $*$ \\
\hline & \multirow[t]{2}{*}{$\mathrm{DON}(\mu \mathrm{M})$} & WWTF comp & 262 & -8 & 0.10 & * \\
\hline & & WWTF grab & 102 & 31 & 0.07 & 0.18 \\
\hline & TON $(\mu \mathrm{M})$ & WWTF comp- $r$ & -11 & 115 & 0.00 & 0.75 \\
\hline & \multirow[t]{2}{*}[\mathrm{PO}_{4}^{3-}]{$(\mu \mathrm{M})$} & WWTF comp & $5.0 \times 10^{-2}$ & 8.0 & 0.05 & 0.30 \\
\hline & & WWTF grab & $4.0 \times 10^{-2}$ & 3.7 & 0.08 & 0.12 \\
\hline \multirow{5}{*}{$\begin{array}{l}1 /\left(\mathrm{NO}_{3}^{-} \text {flux }\right) \\
\left(\mathrm{d} \mathrm{mol}^{-1}\right)\end{array}$} & \multirow[t]{2}{*}{$\delta^{15} \mathrm{~N}_{\mathrm{NO}_{3}}(\% \circ)$} & S & $2.6 \times 10^{4}$ & 6.6 & 0.43 & $* *$ \\
\hline & & $\mathrm{W}$ & $1.9 \times 10^{4}$ & 6.8 & 0.39 & $* *$ \\
\hline & \multirow[t]{2}{*}{$\delta^{18} \mathrm{O}_{\mathrm{NO}_{3}}(\% o)$} & $S$ & $-2.1 \times 10^{4}$ & 4.2 & 0.25 & ** \\
\hline & & $\mathrm{W}$ & $-1.0 \times 10^{4}$ & 4.7 & 0.26 & $* *$ \\
\hline & $\delta^{18} \mathrm{O}_{\mathrm{NO}_{3}}-\operatorname{corr}(\% o)$ & S & $-1.6 \times 10^{4}$ & 3.8 & 0.26 & ** \\
\hline
\end{tabular}



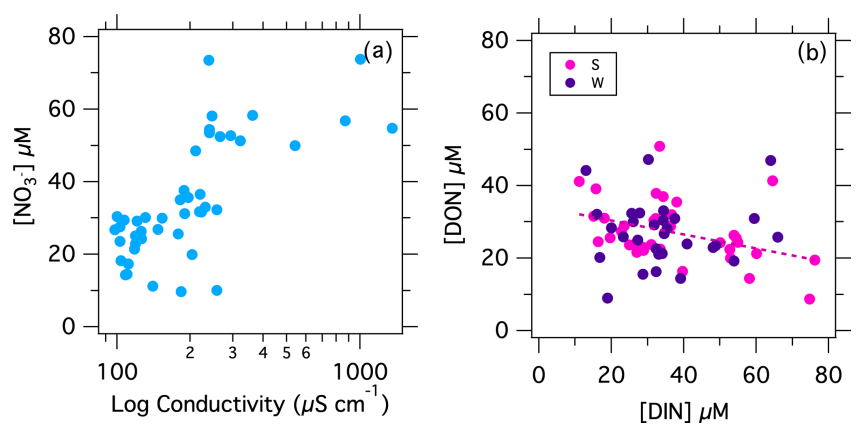

Figure 3. (a) $\left[\mathrm{NO}_{3}^{-}\right]$in weekly samples at the Stillman Bridge vs. conductivity (log scale). (b) Weekly [DON] at the Stillman and Westerly bridges vs. [DIN].

high as $5.9 \mu \mathrm{M}$ during a single sampling event, exhibiting higher concentrations occurring in summer months, thus mirroring $\left[\mathrm{NO}_{3}^{-}\right]$(Fig. 2k). Concentrations of $\mathrm{PO}_{4}^{3-}$ appeared to correlate inversely with discharge, yet only at the Westerly Bridge and not the Stillman Bridge (Fig. 21; Table 1).

The concentration of DON at the bridge sites ranged from 9 to $56 \mu \mathrm{M}$, appeared similar among seasons, and did not show a statistically significant relationship to river discharge (Fig. 2m-n; Table 1). Nevertheless, [DON] and coincident [DIN] were inversely correlated, albeit weakly so, and significantly so only at the Stillman Bridge (Fig. 3b; Table 1). In turn, [PN] exhibited median values of $2.6 \mu \mathrm{M}$ from May through October and $2.9 \mu \mathrm{M}$ during the colder season, showing no values greater than $7 \mu \mathrm{M}$; no correlation of [PN] with river discharge was evident (Fig. S3a-b; Table 1). Concentrations of chlorophyll $a$, which we measured only from June through December, ranged from 0.5 to $12.1 \mu \mathrm{g} \mathrm{L}{ }^{-1}$, with higher values occurring in late summer to early fall. Chlorophyll $a$ showed no correlation with discharge (Fig. S3e-f; Table 1).

The daily riverine flux of dissolved inorganic nitrogen (DIN) delivered to the estuary from the Pawcatuck River, computed from the product of river discharge and the sum of $\left[\mathrm{NO}_{3}^{-}\right]$and $\left[\mathrm{NH}_{4}^{+}\right]$recorded at the bridges, varied $\sim 10$ fold over the annual sampling period, ranging from 0.1 to $1.1\left(\times 10^{5}\right)$ mol of $\mathrm{N}_{\text {DIN }}$ per day - omitting a single outlier of $1.8 \times 10^{5} \mathrm{~mol}$ of $\mathrm{N}_{\text {DIN }}$ per day (Fig. $4 \mathrm{a}$ ). The riverine DIN flux increased directly with river discharge, such that it was lowest in summer, averaging $0.2 \pm 0.1\left(\times 10^{5}\right) \mathrm{mol}$ of $\mathrm{N}_{\text {DIN }}$ per day from May through October (Fig. 4b; Table 1). The riverine DON flux, in turn, ranged from $<0.1$ to $2.0\left(\times 10^{5}\right) \mathrm{mol}$ of $\mathrm{N}_{\text {DON }}$ per day and also increased directly with discharge (Fig. 4c-d; Table 1). The total riverine $\mathrm{N}$ flux (TN flux), which is the sum of respective DIN, DON, and PN fluxes, ranged from 0.2 to $3.0\left(\times 10^{5}\right) \mathrm{mol}$ of $\mathrm{N}_{\mathrm{TN}}$ per day and correlated directly with discharge (Fig. 4e-f; Table 1).
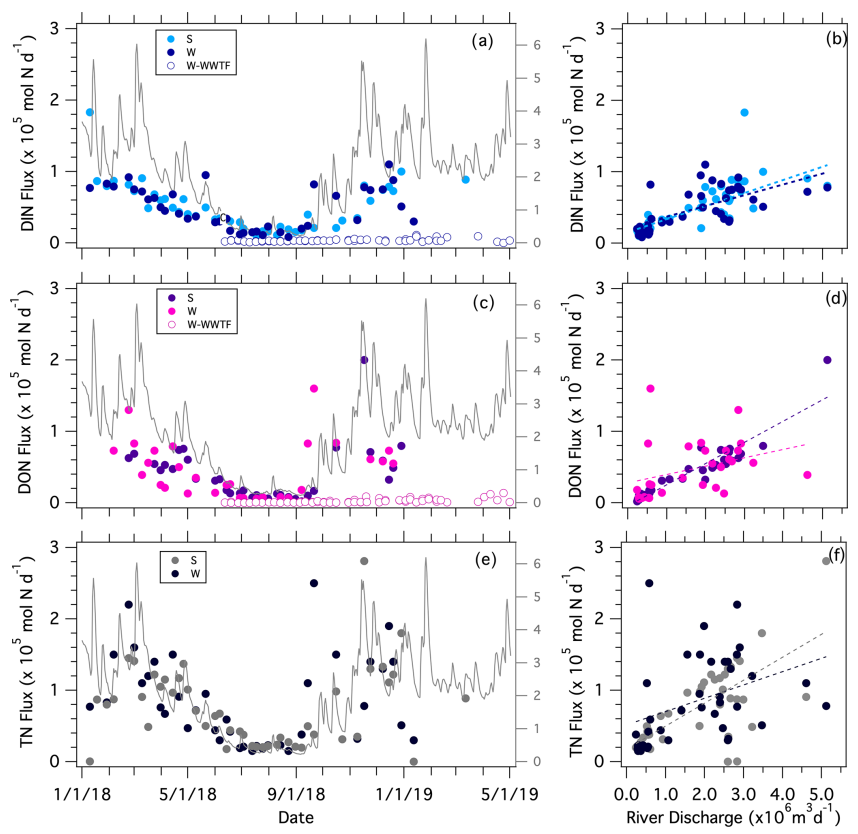

Figure 4. Weekly estimates of N fluxes at the Stillman and Westerly bridges and from the Westerly WWTF vs. sampling date (superposed onto river discharge) and vs. the mean daily river discharge recorded at the Stillman Bridge. The secondary axis in the left-hand panels is the river discharge $\left(\times 10^{6} \mathrm{~m}^{3} \mathrm{~d}^{-1}\right)$. DIN flux vs. (a) sampling date and (b) mean daily river discharge; DON flux vs. (c) sampling date and (d) mean daily river discharge; TN flux (the sum of DIN, DON, and PN) vs. (e) sampling date and (f) mean daily river discharge. Statistical fits of least-square linear regressions are reported in Table 1.

\subsection{WWTF samples}

Nutrient concentrations measured in samples collected weekly at the Westerly WWTF, consisting of both grab and composite samples, ranged from 30 to $527 \mu \mathrm{M}$ for $\left[\mathrm{NO}_{3}^{-}\right]$, 1.3 to $1070 \mu \mathrm{M}$ for $\left[\mathrm{NH}_{4}^{+}\right], 11.7$ to $1168 \mu \mathrm{M}$ for [DON], and 2.7 to $26.5 \mu \mathrm{M}$ for $\left[\mathrm{PO}_{4}^{3-}\right.$ ] (Fig. $5 \mathrm{a}, \mathrm{c}, \mathrm{e}, \mathrm{g}$ ). Concentrations of $\mathrm{NO}_{3}^{-}$and $\mathrm{NH}_{4}^{+}$were similar in grab vs. composite samples (Fig. S4a-b). The $\left[\mathrm{NO}_{3}^{-}\right]$and $\left[\mathrm{NH}_{4}^{+}\right]$measured at UConn were similar to those reported by the Westerly WWTF (Fig. S4c-d). The [DON] measured at UConn showed poor correspondence to the facility-reported [TON] (total organic nitrogen) for the few corresponding sampling dates, although these sample types may arguably not be comparable as the UConn analyses did not include [PN] (Fig. S4e).

Both $\left[\mathrm{NO}_{3}^{-}\right]$and $\left[\mathrm{PO}_{4}^{3-}\right]$ were higher in summer months when facility discharge was lower, at which time $\left[\mathrm{NH}_{4}^{+}\right]$was lower. The concentration of $\mathrm{NO}_{3}^{-}$correlated inversely with the facility-reported discharge, whereas $\left[\mathrm{NH}_{4}^{+}\right]$correlated directly with discharge (Table 1). There was an apparent increase in $[D O N]$ with discharge, albeit with high variability during high flow in winter months, whereas facility-reported 

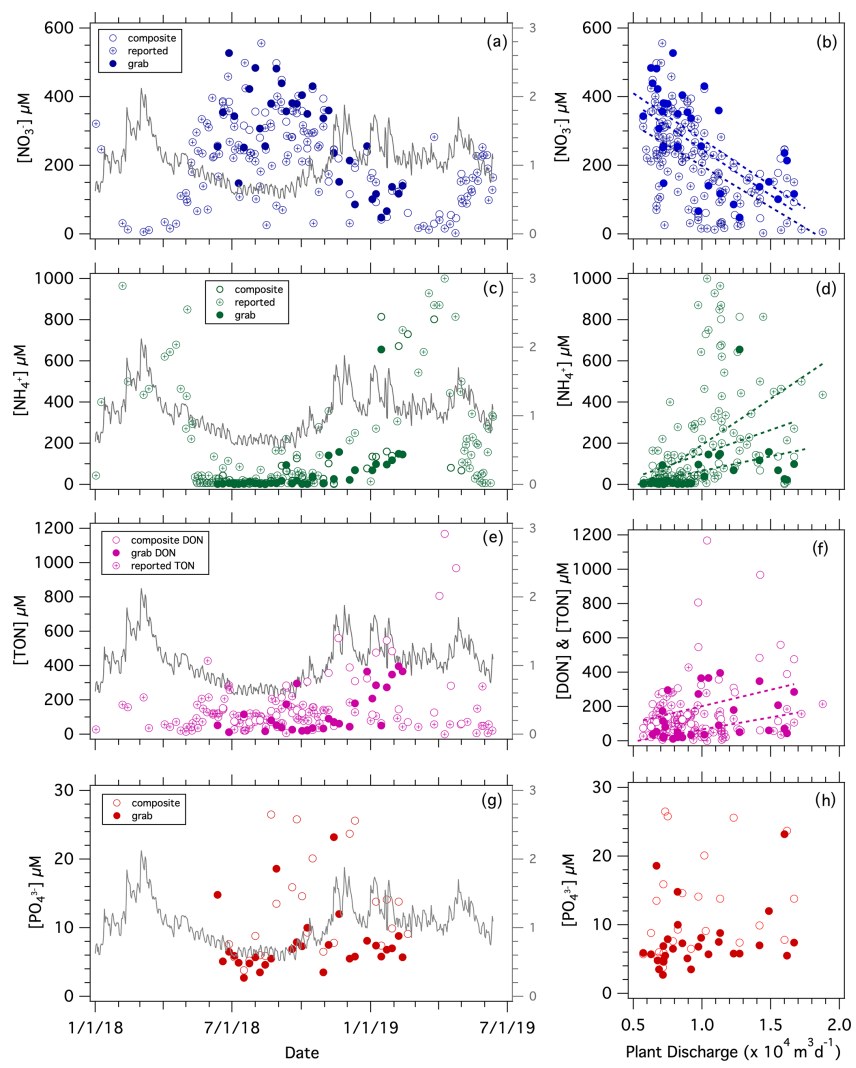

Figure 5. Nutrient discharged from the Westerly WWTF: $\left[\mathrm{NO}_{3}^{-}\right]$ vs. (a) date and (b) facility discharge; $\left[\mathrm{NH}_{4}^{+}\right]$vs. (c) date and (d) facility discharge; [DON] and facility-reported [TON] vs. (e) date and (f) facility discharge; $\left[\mathrm{PO}_{4}^{3-}\right]$ vs. (g) date and (h) facility discharge. The grey line corresponds to the WWTF mean daily water discharge with reference to the secondary axis in the left-hand panels $\left(\times 10^{4} \mathrm{~m}^{3} \mathrm{~d}^{-1}\right)$. Statistical fits of least-square linear regressions are reported in Table 1 .

[TON] did not correlate with discharge (Fig. 5f; Table 1). Our limited $\left[\mathrm{PO}_{4}^{3-}\right]$ measurements were not significantly correlated with facility-reported discharge (Fig. 5h, j; Table 1).

In contrast to the riverine $\mathrm{N}$ fluxes, which increased with river discharge, the DIN and TON fluxes from the Westerly WWTF were remarkably constant and were substantially lower than corresponding riverine fluxes, averaging $3.2 \times 10^{3} \mathrm{~mol}$ of $\mathrm{N}_{\text {DIN }}$ per day, $1.0 \times 10^{3} \mathrm{~mol}$ of $\mathrm{N}_{\text {TON }}$ per day, and $4.1 \times 10^{3}$ mol of $\mathrm{N}_{\mathrm{TN}}$ per day in 2018 (Fig. $4 \mathrm{a}-\mathrm{f}$; Table S1). The daily TN loading at the Westerly WWTF was notably lower than the permitted allowable daily discharge from May through November of $13.5 \times 10^{4}$ mol of $\mathrm{N}_{\mathrm{TN}}$ per day.

\subsection{Along-river samplings}

Samples collected at stations along the length of the river showed both spatial and seasonal patterns in nutrients and $\mathrm{NO}_{3}^{-}$isotope ratios (Figs. 6 , S5). On average, $\left[\mathrm{NO}_{3}^{-}\right]$dif- fered among sampling dates $\left(F_{2,12}=122.4, p<0.0001\right)$ and was lower during the November 2018 sampling than during the May 2018 and March 2019 samplings at all river sites (Tukey honestly significant difference (HSD), both $p<0.05$; Fig. 6b; Table $\mathrm{S} 2)$. $\left[\mathrm{NO}_{3}^{-}\right]$tended to increase along river sections $\left(F_{3,9}=32.1, p<0.0001\right)$, but the specific patterns varied among sampling dates $\left(F_{6,12}=107.2, p<0.0001\right)$. In the source basin at Worden Pond, $\left[\mathrm{NO}_{3}^{-}\right]$ranged from 0.4 to $6 \mu \mathrm{M}$ among sampling events and increased to datespecific maxima of 10 to $65 \mu \mathrm{M}$ between Stations 2 and 4 (Biscuit City Road to Wood River Junction). Concentrations decreased downstream of the Wood River inflow (between river sections 2 and 3) to values as low as $7 \mu \mathrm{M}$ in November and as high as $29 \mu \mathrm{M}$ in March (Tukey HSD, both $p<0.01$ ), although these two sections of the river were similar in May 2018 (Tukey HSD, both $p>0.9$ ). $\left[\mathrm{NO}_{3}^{-}\right]$increased between Potter Hill Dam (Station 11) and the Stillman and Westerly bridges (between sections 3 and 4) during all sampling campaigns (Tukey HSD, all $p<0.05$ ), with final concentrations of $10 \mu \mathrm{M}$ in November and $32 \mu \mathrm{M}$ in March (Fig. 6b).

Values of $\delta^{15} \mathrm{~N}_{\mathrm{NO}_{3}}$ differed among sampling dates $\left(F_{2,15}=16.6, p<0.001\right)$ and along the river $\left(F_{3,9}=26.2\right.$, $p<0.001$; Fig. 6c). On average, values were lower in March 2019, at which time $\left[\mathrm{NO}_{3}^{-}\right]$was relatively elevated, than in May and November 2018 (Tukey HSD: both $p<0.001$ ), although a sample in the uppermost river section (Station 2) had higher $\delta^{15} \mathrm{~N}_{\mathrm{NO}_{3}}$ values in March than in May (see Discussion). Values during the March 2019 sampling ranged from $3.4 \%$ at Station 3 to $6.7 \%$ at the bridges (river Sect. 4). Values in November 2018, which were similar to those in May 2018, ranged from 5.8\%o at Station 3 to $8.5 \%$ at the bridges. $\mathrm{NO}_{3}^{-}$delivered by the Wood River (Station 6) had $\delta^{15} \mathrm{~N}_{\mathrm{NO}_{3}}$ values similar to or greater than those of $\mathrm{NO}_{3}^{-}$ originating upstream in the Pawcatuck River.

In contrast to $\delta^{15} \mathrm{~N}_{\mathrm{NO}_{3}}, \delta^{18} \mathrm{O}_{\mathrm{NO}_{3}}$ values tended to decrease downriver $\left(F_{3,9}=8.6, p<0.01\right.$; Fig. $\left.6 \mathrm{~d}\right)$, despite relatively large variability. Relative maxima between $3.2 \%$ and $5.0 \%$ were apparent at Stations 3 and 4 (river section 2), decreasing to values oscillating between $2.7 \%$ and $4.8 \%$ o toward the bridges $\left(F_{3,9}=8.6, p<0.01\right.$; Fig. $\left.6 \mathrm{~d}\right)$. The $\delta^{18} \mathrm{O}_{\mathrm{NO}_{3}}$ values upriver were generally higher in November (in contrast to $\delta^{15} \mathrm{~N}_{\mathrm{NO}_{3}}$ ) but otherwise occupied comparable ranges among sampling dates. Values contributed by the Wood River were similar to or marginally greater than those upstream in the Pawcatuck River on corresponding dates.

The concentration of $\mathrm{NH}_{4}^{+}$did not vary systematically across river sections $\left(F_{3,9}=3.2, p=0.08\right)$, ranging from 0.4 to $6.8 \mu \mathrm{M}$ (Fig. S5). [ $\left.\mathrm{NH}_{4}^{+}\right]$was greater during the May 2018 sampling than during March or November, and this effect did not vary significantly across the $\operatorname{river}\left(F_{6,12}=2.1, p=0.12\right)$.

The concentration of $\mathrm{PO}_{4}^{3-}$ varied over both space $\left(F_{3,9}=\right.$ $45.2, p<0.0001)$ and time $\left(F_{2,12}=72.0, p<0.0001\right)$, and these effects were non-additive $\left(F_{6,12}=32.2, p<0.0001\right)$. $\left[\mathrm{PO}_{4}^{3-}\right]$ was relatively homogeneous across the river sections in May 2018 (Tukey HSD, all pairwise $p>0.05$ ) but 


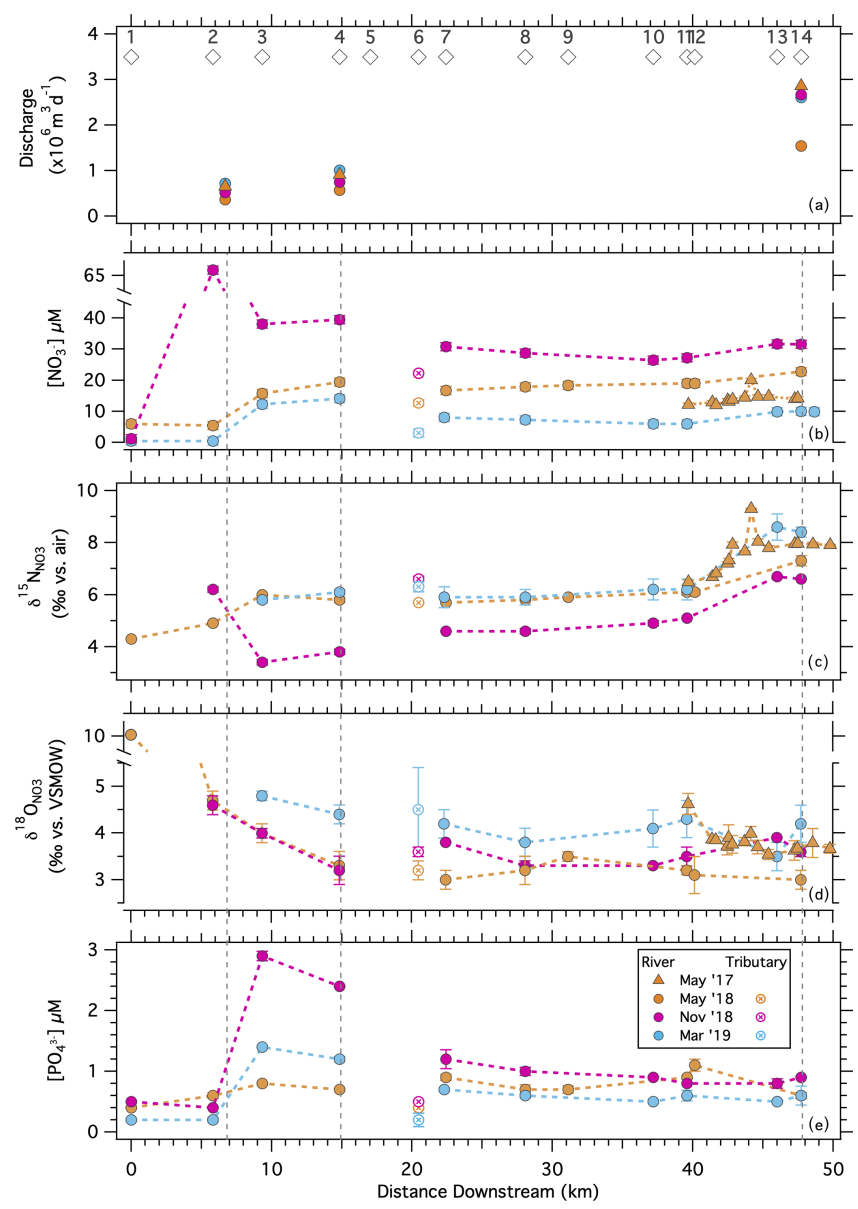

Figure 6. Solute concentrations and nitrate isotopologue ratios observed along the Pawcatuck River from its origin at Worden Pond to the Westerly Bridge during along-river sampling campaigns. (a) Mean daily river discharge recorded at three flow gauges along the Pawcatuck River during the sampling campaigns: (b) $\left[\mathrm{NO}_{3}^{-}\right]$, (c) $\delta^{15} \mathrm{~N}_{\mathrm{NO}_{3}}$, (d) $\delta^{18} \mathrm{O}_{\mathrm{NO}_{3}}$, and (e) $\left[\mathrm{PO}_{4}^{3-}\right]$ measured at stations along-river. Open circles designate the lower Wood River that inflows to the Pawcatuck.

increased in river section 2 in both March and November compared to neighboring sections up- and downstream (Tukey HSD, all $p<0.01$; Fig. 6e). Across all sampling dates, $\left[\mathrm{PO}_{4}^{3-}\right]$ ranged from 0.2 to $0.5 \mu \mathrm{M}$ in and near Worden Pond (river section 1) and peaked at values between 0.7 and $2.9 \mu \mathrm{M}$, in river section 2. Further downstream, $\left[\mathrm{PO}_{4}^{3-}\right]$ ranged from 0.5 to $1.2 \mu \mathrm{M}$. $\left[\mathrm{PO}_{4}^{3-}\right]$ in the Wood River (Station 6) was relatively low and similar to that at Worden.

\section{Discussion}

\subsection{Nutrient source attribution}

At the Stillman and Westerly bridges, concentrations of $\mathrm{NO}_{3}^{-}$ - the principal component of DIN - scaled inversely with dis- charge, wherein higher concentrations occurred during summer at low base flow. This relationship suggests the bulk of riverine DIN during low base flow originated from groundwater and point sources along the river catchment. Given that there is only one documented point source upstream of Stillman and Westerly bridges, we surmise that DIN at low base flow originated predominantly from groundwater and partially from discharge at Kenyon Industries. That $\left[\mathrm{NO}_{3}^{-}\right]$at the Stillman Bridge increased in proportion to conductivity also suggests a groundwater source for bulk riverine nutrients at low base flow, although an analogous trend could admittedly arise from loading by a point source.

During wetter months in winter, increased input of shallow groundwater and surface runoff (henceforth collectively referred to as "shallow flow") diluted the low-base-flow $\left[\mathrm{NO}_{3}^{-}\right]$, thus lowering riverine concentrations, a dynamic documented in other temperate rivers (Mulholland and Hill, 1997; Dubrovski et al., 2010). Nevertheless, the daily DIN flux increased with discharge, indicating that DIN is also imported to the river by shallow flow, albeit at a lower concentration than low-base-flow DIN. From the slope of the DIN flux-to-discharge relationship, the daily DIN flux increased by $2.6 \pm 0.3\left(\times 10^{4}\right) \mathrm{mol}$ of $\mathrm{N}$ per additional $10^{6} \mathrm{~m}^{3}$ of discharge, suggesting the DIN concentration of shallow flow from the catchment averaged $26 \pm 3 \mu \mathrm{M}$ (Table 1 ). The relationship between [DIN] and river discharge, which we initially presumed linear, is then better described by a two-endmember mixing curve comprised of low-base-flow [DIN] mixing with shallow-flow [DIN]:

$$
\begin{aligned}
{[\mathrm{DIN}]_{i} } & =\left[\left(Q_{i}-2.2 \times 10^{8}\right) \cdot 26 \times 10^{-6}\right. \\
& \left.+2.2 \times 10^{8} \cdot 64 \times 10^{-6}\right] / Q_{i} .
\end{aligned}
$$

The term $Q_{i}$ is mean river discharge on day $i$ in units of $\mathrm{Ld}^{-1}$, from which the subtracted value of $2.2 \times 10^{8} \mathrm{Ld}^{-1}$ is the asymptote of low base flow (i.e., the lowest river discharge observed in 2018), and [DIN] $]_{i}$ is the corresponding concentration in units of $\mathrm{mol} \mathrm{L}^{-1}$. The low-base-flow [DIN] end-member of $64 \pm 9 \mu \mathrm{M}$ derives from the best fit of the equation to the data. Implicit in Eq. (4) is the assumption of negligible in-river $\mathrm{N}$ consumption, a notion supported by the low incident [PN]; we return to this dynamic further below. The mixing relationship can serve to approximate the DIN flux from the Pawcatuck River into Little Narragansett Bay based on the river discharge recorded continually by the USGS at the Stillman Bridge. The annual DIN load returned by this function based on the continuous (15 min interval) discharge records at the Stillman Bridge for 2018 is $21.4 \times 10^{6} \mathrm{~mol} \mathrm{~N} \mathrm{yr}^{-1}$, slightly higher than our direct estimate of $20.2( \pm 2.0) \times 10^{6} \mathrm{~mol} \mathrm{~N} \mathrm{yr}^{-1}$, yet reassuringly within the uncertainty (Table 2 ).

The inverse correlation of [DON] with [DIN], in turn, suggests that $[\mathrm{DON}]$ is transported into the river by shallow 


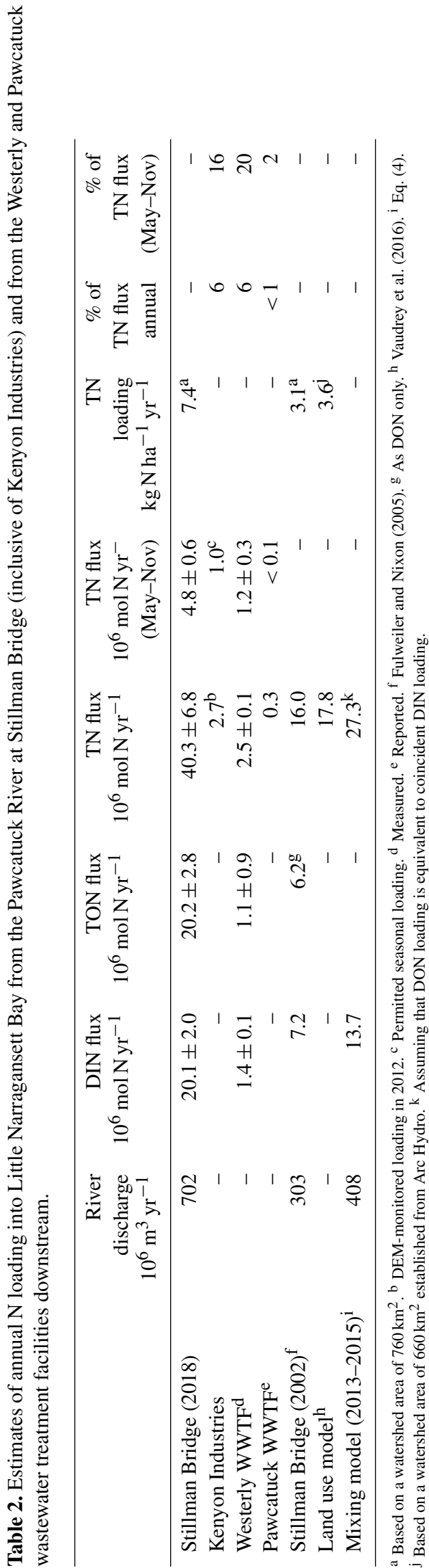

ground water and surface flow from the catchment. Shallow flow, which increases with increased precipitation, is apt to transport organic material from soils and surface plant materials (Elwood and Turner, 1989; Mulholland et al., 1990; Pabich et al., 2001). The import of DON by shallow flow is consistent with the visibly elevated concentrations of riverine tannins. In this regard, the lack of direct correlation of [DON] to discharge is surprising but may be masked by the relatively high variability of the [DON] measurements, even between replicate water samples.

Nutrient loading from the Pawcatuck River into Little Narragansett Bay was investigated previously by Fulweiler and Nixon (2005). As discerned herein, they observed an inverse relationship of [DIN] to discharge from biweekly measurements at the Stillman Bridge over an annual cycle. Contrary to our interpretations, however, they argued that the decline in [DIN] with discharge was due to seasonal uptake by vegetation within the catchment, specifically during spring. They observed the lowest [DIN] in spring, corresponding to the highest discharge during their annual study period. Here, we otherwise argue that increased water discharge dilutes the low-base-flow nutrients derived from groundwater and point source discharge, such that concentrations are most elevated at low base flow. While the concentration is lower during periods of high river flow, the riverine DIN flux nevertheless increases with discharge, carrying nutrients imported by shallow flow.

Fulweiler and Nixon (2005) also observed that [DON] and [DIN] were inversely correlated, as in the current study, and further detected a positive correlation between [DON] and discharge, corroborating our earlier inference that such a relationship should be manifest. They reasoned that the greater remineralization of bioavailable DON in summer, at low discharge, could explain this trend, given the greater in-river residence time of DON at low base flow. While the mineralization of DON may be significant during the warm season (e.g., Brookshire et al., 2005), we otherwise contend that the increased [DON] with discharge may reflect import from the catchment via shallow flow.

The mean $[D I N]$ imported by shallow flow inferred herein is relatively low $(\sim 26 \mu \mathrm{M})$, in the range of 15 to $70 \mu \mathrm{M}$ generally observed in surface and shallow groundwater of undeveloped catchments across the US, and substantially lower than the range of 100 to $700 \mu \mathrm{M}$ observed in shallow streams draining agriculture catchments (Dubrovsky et al., 2010). However, it is greater than the [DIN] of $\leq 5 \mu \mathrm{M}$ recorded in shallow streams draining pristine forested catchments in the northeast USA, which are otherwise dominated by DON (Dickerman et al., 1989; Hedin et al., 1998). The [DIN] of $\sim 64 \mu \mathrm{M}$ recorded here at low base flow, which likely reflects that of deeper groundwater (barring a substantial point source input) is also within the range reported for groundwater $\mathrm{NO}_{3}^{-}$ in undeveloped catchments, albeit at the higher end of this range (of 7 to $75 \mu \mathrm{M}$; Mueller et al., 1995) and falling within the range reported for groundwater $\mathrm{NO}_{3}^{-}$in southern $\mathrm{RI}(0$ 


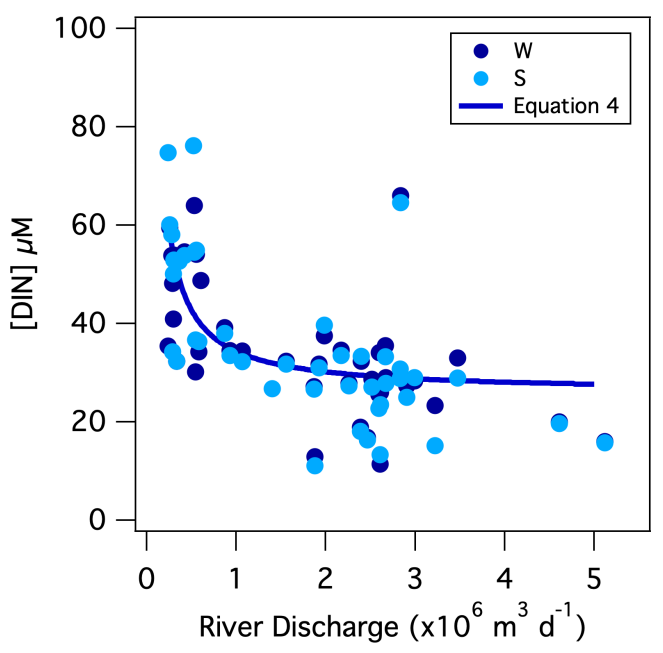

Figure 7. Mixing curve of low-base-flow $\left[\mathrm{NO}_{3}^{-}\right]$with shallow-flow $\left[\mathrm{NO}_{3}^{-}\right]$superposed onto weekly measurements of $\left[\mathrm{NO}_{3}^{-}\right]$vs. the corresponding mean daily discharge at the Stillman Bridge (Eq. 4).

$91 \mu \mathrm{M}$; Moran et al., 2014). The mean low-base-flow [DIN] observed here is substantially lower than concentrations typical of groundwater in agricultural catchments but higher than the [DIN] that was observed in the groundwater reservoir of the upper Wood River in the 1980s (median $\leq 11 \mu \mathrm{M}$; Dickerman et al., 1989; Dickerman and Bell, 1993) - suggesting that anthropogenic input to the deeper groundwater $\mathrm{N}$ reservoir of the Pawcatuck watershed has increased over time.

\subsection{Corroborating insights from $\mathrm{NO}_{3}^{-}$isotope ratios}

We turn to the $\mathrm{N}$ and $\mathrm{O}$ isotope composition of $\mathrm{NO}_{3}^{-}$to further investigate relationships of nutrients with river discharge and to characterize $\mathrm{N}$ sources and cycling in the river. Like $\left[\mathrm{NO}_{3}^{-}\right]$, the isotope ratios of $\mathrm{NO}_{3}^{-}$co-varied with discharge. Values of $\delta^{15} \mathrm{~N}_{\mathrm{NO}_{3}}$ decreased with discharge, suggesting that (a) $\mathrm{NO}_{3}^{-}$added by shallow flow had lower $\delta^{15} \mathrm{~N}_{\mathrm{NO}_{3}}$ values than low-base-flow $\mathrm{NO}_{3}^{-}$, and/or (b) $\delta^{15} \mathrm{~N}_{\mathrm{NO}_{3}}$ values at low base flow increased during warmer months compared to their groundwater end-member due to biological cycling in-river. Concurrently, $\delta^{18} \mathrm{O}_{\mathrm{NO}_{3}}$ values increased with discharge, suggesting that (c) $\mathrm{NO}_{3}^{-}$added by shallow flow had higher $\delta^{18} \mathrm{O}_{\mathrm{NO}_{3}}$ values than low-base-flow $\mathrm{NO}_{3}^{-}$, and/or (d) $\delta^{18} \mathrm{O}_{\mathrm{NO}_{3}}$ values decreased in summer due to biological cycling. We consider these hypotheses in turn.

\subsubsection{Sources of DIN in shallow flow evidenced from $\delta^{15} \mathrm{~N}_{\mathrm{NO}_{3}}$ values}

In order to evaluate whether the lower $\delta^{15} \mathrm{~N}$ DIN values observed at higher discharge can be explained by the addition of relatively low $\delta^{15} \mathrm{~N}$ DIN by shallow flow, we plotted the $\delta^{15} \mathrm{~N}_{\mathrm{NO}_{3}}$ values recorded at the Stillman Bridge vs. the inverse of the corresponding $\mathrm{NO}_{3}^{-}$flux (i.e., an adapted Keel- ing plot; Keeling, 1958, 1961; Fig. 8a). Because we lack measurements of the $\delta^{15} \mathrm{~N}$ values of the incident $\mathrm{NH}_{4}^{+}$pool (which we could not assess due to an analytical interference from dissolved organic material; see Zhang et al., 2007), we assume that the $\mathrm{N}$ isotope composition of $\mathrm{NO}_{3}^{-}$captures that of bulk DIN, on the basis that $\mathrm{NH}_{4}^{+}$imported from the catchment was largely nitrified in-river, wherein $\mathrm{NH}_{4}^{+}$accounted for only a small fraction of the DIN reservoir. The riverine $\delta^{15} \mathrm{~N}_{\mathrm{NO}_{3}}$ data conform to a linear relationship expected for the addition of DIN with a lower mean $\delta^{15} \mathrm{~N}$ to the low-baseflow reservoir (Table 1). The intercept of the resulting linear regression suggests that the $\mathrm{NO}_{3}^{-}$associated with increased discharge had a mean $\delta^{15} \mathrm{~N}$ value of $6.7 \pm 0.2 \%$ (Table 1 ), compared to a low-base-flow value of $\sim 8 \%$ observed at the bridges. The average $\delta^{15} \mathrm{~N}_{\mathrm{NO}_{3}}$ value of atmospheric $\mathrm{NO}_{3}^{-}$in rainwater was $-2.5 \pm 2.1 \%$ (Sect. S1; Fig. S2), indicating that $\mathrm{NO}_{3}^{-}$added by shallow flow did not predominantly originate from direct atmospheric deposition as uncycled atmospheric $\mathrm{NO}_{3}^{-}$. While the $\delta^{15} \mathrm{~N}_{\mathrm{NO}_{3}}$ of atmospheric $\mathrm{NO}_{3}^{-}$could conceivably be fractionated by biological cycling in-river following its import by shallow flow, increased discharge occurred largely during the cold season, at which time biological cycling in-river was presumably curtailed. Thus, we surmise that the DIN added by shallow flow did not originate from direct atmospheric deposition as uncycled atmospheric $\mathrm{NO}_{3}^{-}$but rather derived from catchment soils and shallow groundwater. The $\delta^{15} \mathrm{~N}_{\mathrm{NO}_{3}}$ end-member value of $6.7 \%$ is in the upper range observed for soil $\mathrm{NO}_{3}^{-}$in temperate forested catchments (Mayer et al., 2002; Barnes and Raymond, 2009). While the net sources of reactive $\mathrm{N}$ to forested soils are atmospheric deposition and biological $\mathrm{N}_{2}$ fixation - which have relatively low $\delta^{15} \mathrm{~N}$ values $(\leq 0 \%)$ - partial denitrification in soils and shallow groundwater increases the $\delta^{15} \mathrm{~N}$ of the soil $\mathrm{N}$ reservoir to values of $\sim 5 \%$ (Amundson et al., 2003; Houlton et al., 2006; McMahon and Böhlke, 2006; Houlton and Bai, 2009). The $\mathrm{NO}_{3}^{-}$imported by shallow flow draining urbanized systems has comparatively higher $\delta^{15} \mathrm{~N}_{\mathrm{NO}_{3}}$ values ( $\geq 10 \%$; e.g., Divers et al., 2014), while $\mathrm{NO}_{3}^{-}$in soils and shallow groundwater in agricultural systems generally falls within a lower range of values between $2 \% o-4 \%$ o (Green et al., 2008; Böhlke et al., 2009; Lin et al., 2019). The watershed of the Pawcatuck River is largely forested, yet hosts agricultural and urbanized sections that ostensibly contributed to the mean $\delta^{15} \mathrm{~N}_{\mathrm{NO}_{3}}$ end-member imported by shallow flow. Thus, while DIN added to the river by shallow flow at high discharge had a mean $\delta^{15} \mathrm{~N}$ value consistent with expectations for a largely forested catchment, inputs from agricultural and urbanized catchments may be rendered undiscernible due to their opposing contributions to the mean $\delta^{15} \mathrm{~N}_{\mathrm{NO}_{3}}$ value in shallow flow. 


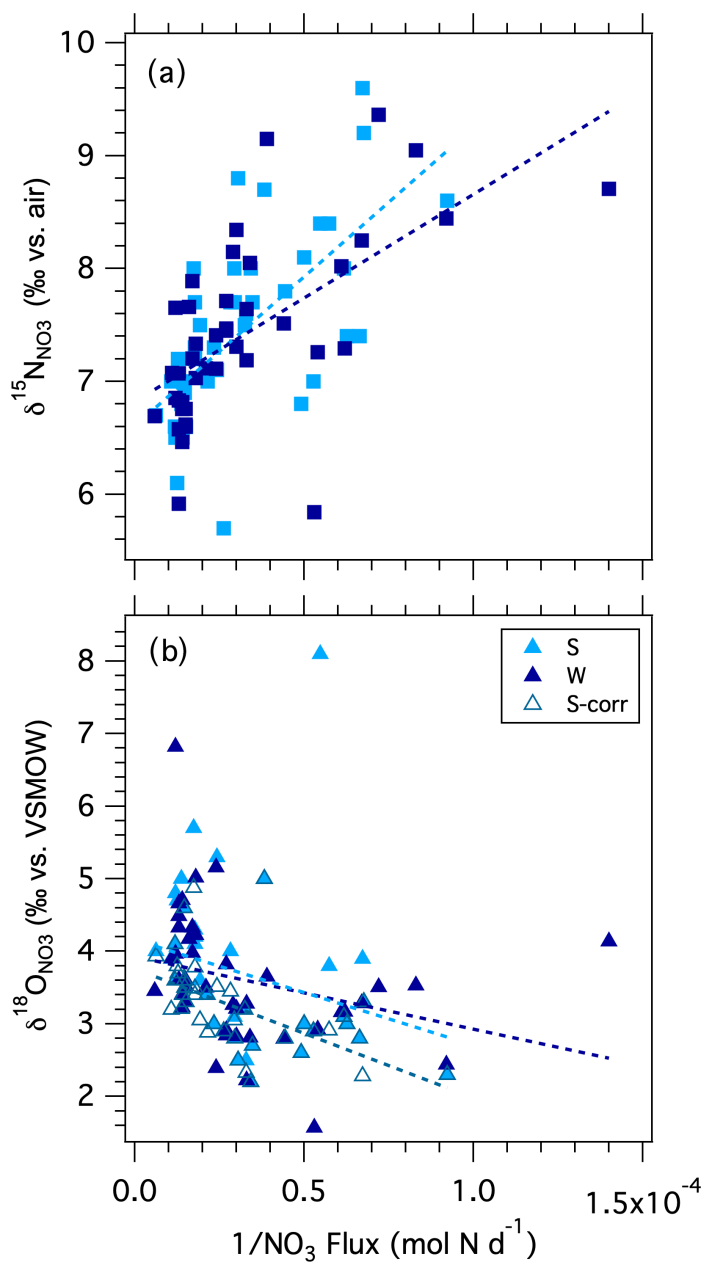

Figure 8. Modified Keeling plot of $\mathrm{NO}_{3}^{-}$isotopologue ratios at the Westerly and Stillman bridges vs. the inverse of the daily $\mathrm{NO}_{3}^{-}$ flux: (a) $\delta^{15} \mathrm{~N}_{\mathrm{NO}_{3}}$ vs. the inverse of the $\mathrm{NO}_{3}^{-}$flux; (b) $\delta^{18} \mathrm{O}_{\mathrm{NO}_{3}}$ and $\delta^{18} \mathrm{O}_{\mathrm{NO}_{3}}$ corrected for atmospheric $\mathrm{NO}_{3}^{-}$vs. the inverse of the $\mathrm{NO}_{3}^{-}$flux.

\subsubsection{Negligible fraction of uncycled atmospheric $\mathrm{NO}_{3}^{-}$ confirmed by $\mathrm{O}$ isotope ratios}

The inference that uncycled atmospheric $\mathrm{NO}_{3}^{-}$did not contribute substantially to the increased $\mathrm{NO}_{3}^{-}$flux at higher discharge is corroborated by the $\Delta^{17} \mathrm{O}_{\mathrm{NO}_{3}}$ measurements at the Stillman Bridge. The low values of $\mathrm{NO}_{3}^{-}$in rainwater observed evidenced only a slight contribution of $<3 \%$ uncycled atmospheric $\mathrm{NO}_{3}^{-}$to total riverine $\mathrm{NO}_{3}^{-}$in a few samples, suggesting efficient processing of atmospheric $\mathrm{NO}_{3}^{-}$in soil shallow groundwater (Mengis et al., 2001; Barnes et al., 2008). This observation is further echoed in a recent metaanalysis of North American rivers, wherein the contribution of uncycled atmospheric $\mathrm{NO}_{3}^{-}$to base flow was inferred to be generally modest (Sebestyen et al., 2019). The $\mathrm{NO}_{3}^{-}$delivered to the Pawcatuck River by shallow flow evidently orig- inated from a reservoir that was biologically cycled within catchment soils - and potentially in-river - thus losing its atmospheric $\Delta{ }^{17} \mathrm{O}$ signature.

A Keeling plot of $\delta^{18} \mathrm{O}_{\mathrm{NO}_{3}}$ values vs. the inverse of the $\mathrm{NO}_{3}^{-}$flux at the bridges suggests that $\mathrm{NO}_{3}^{-}$added by surface flow had a mean $\delta^{18} \mathrm{O}_{\mathrm{NO}_{3}}$ value of $4.5 \pm 0.4 \%$ o (Fig. 8b; Table 1), compared to a mean low-base-flow value of $2.8 \pm 0.2 \%$. Although the contribution of uncycled atmospheric $\mathrm{NO}_{3}^{-}$to the riverine reservoir was modest, we nevertheless consider that the increase in $\delta^{18} \mathrm{O}_{\mathrm{NO}_{3}}$ values with discharge may derive in part from uncycled atmospheric $\mathrm{NO}_{3}^{-}$, given the direct relationship of $\Delta^{17} \mathrm{O}_{\mathrm{NO}_{3}}$ to discharge, and considering the characteristically elevated $\delta^{18} \mathrm{O}_{\mathrm{NO}_{3}}$ values of $60 \%$ - $80 \%$ observed in the local rainwater $\mathrm{NO}_{3}^{-}$. Indeed, when the weighted contribution of atmospheric $\mathrm{NO}_{3}^{-}$is subtracted from individual $\delta^{18} \mathrm{O}_{\mathrm{NO}_{3}}$ values (attributed from corresponding $\Delta^{17} \mathrm{O}$ measurements, accounting for precipitation-dependent differences in the mean $\Delta^{17} \mathrm{O}$ and $\delta^{18} \mathrm{O}_{\mathrm{NO}_{3}}$ values of rainwater), the intercept of the Keeling plot decreases slightly to $3.8 \pm 0.2 \%$, nevertheless remaining greater than the $\delta^{18} \mathrm{O}_{\mathrm{NO}_{3}}$ of low-base-flow $\mathrm{NO}_{3}^{-}$ (Table 1). The increase in $\delta^{18} \mathrm{O}_{\mathrm{NO}_{3}}$ with increasing discharge is thus partially explained by the small component of uncycled atmospheric $\left[\mathrm{NO}_{3}^{-}\right]$with elevated $\delta^{18} \mathrm{O}_{\mathrm{NO}_{3}}$ values.

The $\delta^{18} \mathrm{O}_{\mathrm{NO}_{3}}$ signature of $3.8 \%$ or $\mathrm{NO}_{3}^{-}$added with increasing discharge (minus the uncycled atmospheric $\mathrm{NO}_{3}^{-}$) is in the range generically observed for soil $\mathrm{NO}_{3}^{-}$(Kendall et al., 2007; Michener and Lajtha, 2007). It has traditionally been ascribed to that expected for newly nitrified $\mathrm{NO}_{3}^{-}$, based on an empirical metric stipulating that the $\delta^{18} \mathrm{O}_{\mathrm{NO}_{3}}$ values produced by nitrification derive from the fractional contribution of the reactants, namely $1 / 3 \delta^{18} \mathrm{O}$ of $\mathrm{O}_{2}+2 / 3$ $\delta^{18} \mathrm{O}$ of $\mathrm{H}_{2} \mathrm{O}$ (Andersson and Hooper, 1983; Hollocher 1984; Kendall et al., 2007). Considering that the $\delta^{18} \mathrm{O}_{\mathrm{H}_{2} \mathrm{O}}$ of Pawcatuck River water is $-7 \%$ and the $\delta^{18} \mathrm{O}_{\mathrm{O}_{2}}$ of atmospheric oxygen is $\sim 23.5 \%$ o (Kroopnick and Craig, 1972), the nitrification $\delta^{18} \mathrm{O}_{\mathrm{NO}_{3}}$ value thus expected is on the fortuitous order of $3.2 \%$. This empirical metric, however, demonstrably overlooks substantive isotope effects associated with $\mathrm{O}$-atom incorporation into the $\mathrm{NO}_{3}^{-}$molecule during nitrification and isotopic exchange of the nitrite intermediate with water, which otherwise give way to nitrified $\mathrm{NO}_{3}^{-}$whose $\delta^{18} \mathrm{O}_{\mathrm{NO}_{3}}$ value is close to that of ambient water (Sigman et al., 2009; Casciotti et al., 2008; Buchwald and Casciotti, 2010; Snider et al., 2010; Boshers et al., 2019). This consideration explains frequent observations of relatively low $\delta^{18} \mathrm{O}_{\mathrm{NO}_{3}}$ in some soils and saturated systems, which are not explained by simple fractional contribution of reactants (Hinkle et al., 2008; Xue et al., 2009; Fang et al., 2012; Veale et al., 2019). Thus, we posit that the $\mathrm{O}$ isotope composition of the $\mathrm{NO}_{3}^{-}$imported into the river with increased discharge, which is typical of that in soils and shallow groundwater, does not strictly indicate that shallow-flow $\mathrm{NO}_{3}^{-}$originated from proximate nitrification therein, as generally presumed. It also signals that $\mathrm{NO}_{3}^{-}$underwent partial denitrification in soils and shallow 
groundwater, resulting in a coupled increase in its $\delta^{15} \mathrm{~N}$ and $\delta^{18} \mathrm{O}$ relative to source values (Houlton et al. 2006; Granger and Wankel, 2016; Boshers et al. 2019). Although increased discharge occurred largely in winter, some in-river biological cycling during colder months could additionally influence the shallow-flow $\delta^{18} \mathrm{O}_{\mathrm{NO}_{3}}$ end-member, specifically reducing it from its soil value due to the nitrification of incident $\mathrm{NH}_{4}^{+}$. Thus, $\delta^{18} \mathrm{O}_{\mathrm{NO}_{3}}$ values imported by shallow flow, once adjusted for modest contributions of uncycled atmospheric $\mathrm{NO}_{3}^{-}$, fall within the range typically observed in soils, potentially modified by nitrification in-river.

\subsubsection{Values of $\delta^{15} \mathrm{~N}_{\mathrm{NO}_{3}}$ at low base flow reflect groundwater DIN}

The higher $\delta^{15} \mathrm{~N}_{\mathrm{NO}_{3}}$ values at low base flow compared to shallow flow may derive directly from those of the groundwater end-members and point source(s). The $\delta^{15} \mathrm{~N}_{\mathrm{NO}_{3}}$ values in deeper groundwater are generally higher than in shallower groundwater above, more fractionated by denitrification in the saturated zone (e.g., Böhlke et al., 2006). Alternatively, the higher $\mathrm{NO}_{3}^{-}$isotope ratios at low base flow may result from increased biological cycling in summer - modifying the isotope composition of low-base-flow $\mathrm{NO}_{3}^{-}$relative to its groundwater and/or point source values. The expectation of increased biological activity in summer months is consistent with the incident decrease in $\left[\mathrm{NH}_{4}^{+}\right]$with lower discharge, which can be explained by a seasonal increase in algal assimilation and nitrification. Fulweiler and Nixon (2005) similarly observed lower $\left[\mathrm{NH}_{4}^{+}\right]$in the summer but saw no correlation to river discharge, further supporting our contention that increased seasonal biological cycling underlies the $\left[\mathrm{NH}_{4}^{+}\right]$dynamics, rather than river discharge.

The extent to which the coincident $\mathrm{NO}_{3}^{-}$pool is also assimilated during summer months - and isotopically fractionated - is unclear. The fraction of the $\mathrm{NO}_{3}^{-}$pool assimilated by algae may be modest, even in summer, on the basis that the phytoplankton biomass was relatively small due to the high tannin content of the river water, which limited light penetration. Median chlorophyll $a$ concentrations in summer were $\sim 1.3 \mu \mathrm{g} \mathrm{L}^{-1}$ at the Stillman and Westerly bridges - save for late summer where higher concentrations were detected while the median [PN] was $\sim 2.5 \mu \mathrm{M}$ and no greater than $7 \mu \mathrm{M}$. There are, however, populations of emergent plants along some shallow reaches of the river, which may assimilate $\mathrm{NO}_{3}^{-}$as well as reduced $\mathrm{N}$ substrates. Nevertheless, the inference that the riverine $\mathrm{NO}_{3}^{-}$pool is minimally assimilated, even in summer, appears consistent with along-river distribution of $\mathrm{NO}_{3}^{-}$isotope ratios. If a sizable fraction of the incident $\mathrm{NO}_{3}^{-}$pool were assimilated into biomass during summer months, both the $\delta^{15} \mathrm{~N}_{\mathrm{NO}_{3}}$ and $\delta^{18} \mathrm{O}_{\mathrm{NO}_{3}}$ values of low-base-flow $\mathrm{NO}_{3}^{-}$would expectedly increase in proportion to the fraction of $\mathrm{NO}_{3}^{-}$assimilated (Granger et al., 2004; Johannsen et al., 2008). However, the $\delta^{15} \mathrm{~N}_{\mathrm{NO}_{3}}$ increase along-river observed during the seasonal surveys, which could be construed as signaling partial assimilation of riverine $\mathrm{NO}_{3}^{-}$, was not matched by coincident along-river increases in $\delta^{18} \mathrm{O}_{\mathrm{NO}_{3}}$ values. Similarly, [PN] and chlorophyll $a$ did not increase along-river, as would otherwise be expected for the progressive and sizable conversion of the $\mathrm{NO}_{3}^{-}$pool into the particulate pools (Fig. S6c-d). Thus, we rule out a dominant influence of algal assimilation in fractionating the riverine $\mathrm{NO}_{3}^{-}$isotope ratios.

A more nuanced framework from which to interpret the $\mathrm{NO}_{3}^{-}$isotope ratios is afforded by the concept of riverine nutrient spiraling, namely, the continual assimilation of nutrients in the water column, the remineralization of organic material in sediments, and the return of remineralized nutrients to the water column where they can undergo assimilation into new biomass (reviewed by Ensign and Doyle, 2006; Harvey et al., 2013). A small fraction of the $\mathrm{NO}_{3}^{-}$ pool is likely assimilated during the growing season, resulting in the production of PN with a lower $\delta^{15} \mathrm{~N}$ than coincident $\mathrm{NO}_{3}^{-}$due to $\mathrm{N}$ isotope fractionation during assimilation (Needoba et al., 2003; Fig. 9). Considering the small summertime pools of $\mathrm{PN}$ and $\mathrm{NH}_{4}^{+}$relative to the $\mathrm{NO}_{3}^{-}$pool, $\delta^{15} \mathrm{~N}_{\mathrm{NO}_{3}}$ values will be minimally fractionated by assimilation. Moreover, the concomitant recycling of PN and its subsequent nitrification will ostensibly regenerate $\mathrm{NO}_{3}^{-}$with a $\delta^{15} \mathrm{~N}_{\mathrm{NO}_{3}}$ value roughly equivalent to that assimilated into organic material then ammonified - given an approximate steady state between $\mathrm{NO}_{3}^{-}$assimilation and nitrification such that $\delta^{15} \mathrm{~N}_{\mathrm{NO}_{3}}$ values will not incur a progressive increase from continual assimilation along-river. These dynamics will result in little net change in riverine $\delta^{15} \mathrm{~N}_{\mathrm{NO}_{3}}$ values relative to the mean catchment end-member.

The $\mathrm{NO}_{3}^{-}$isotope ratios could, however, be influenced by denitrification in-river (Kellman and Hillaire-Marcel, 1998; Fig. 9). While direct benthic denitrification does not communicate an isotope enrichment to $\mathrm{NO}_{3}^{-}$in the overlying water column due to a reservoir effect (Brandes and Devol, 1997; Sebilo et al., 2003; Lehmann et al., 2005), $\delta^{15} \mathrm{~N}$ - and $\delta^{18} \mathrm{O}-$ enriched $\mathrm{NO}_{3}^{-}$from the sediment depth of denitrification can be entrained into the water column by hyporheic flows in the riparian zone (Sebilo et al., 2003). Moreover, coupled nitrification-denitrification can fractionate the $\mathrm{N}$ isotopologues of $\mathrm{NH}_{4}^{+}$in surface sediments in proportion to the corresponding fraction of nitrified $\mathrm{NO}_{3}^{-}$lost concurrently to denitrification, thus contributing to an increase in $\delta^{15} \mathrm{~N}$ of the water column reactive $\mathrm{N}$ reservoir (Brandes and Devol, 1997; Granger et al., 2011). The along-river increase in $\delta^{15} \mathrm{~N}_{\mathrm{NO}_{3}}$ values could then result from isotopic fractionation by sedimentary denitrification. Yet a downstream increase in $\delta^{15} \mathrm{~N}_{\mathrm{NO}_{3}}$ was notably apparent in all seasons, not only in summer. On the presumption that water column and benthic $\mathrm{N}$ cycling were substantially reduced during the March 2019 sampling when river waters were colder (average temperature of $5.9^{\circ} \mathrm{C}$ ), we surmise that the increase in $\delta^{15} \mathrm{~N}_{\mathrm{NO}_{3}}$ values along-river arises principally from differences in the $\delta^{15} \mathrm{~N}$ of DIN input from respective reaches of the catchment 

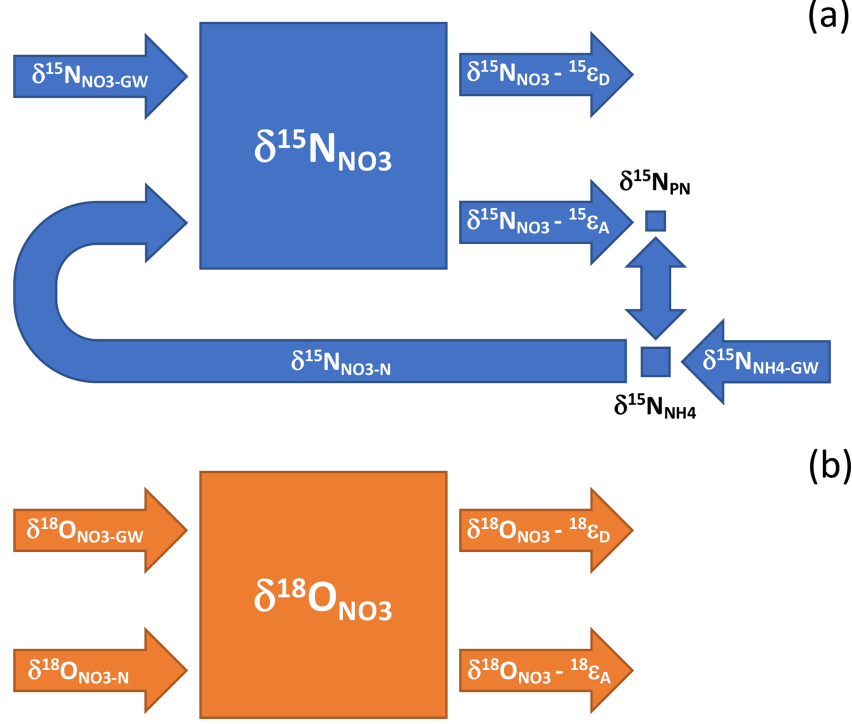

(b)

Figure 9. Conceptual illustration of the influence of nutrient spiraling on the $\mathrm{N}$ and $\mathrm{O}$ isotope ratios of riverine $\mathrm{NO}_{3}^{-}$. Nutrient spiraling describes the cycling of nutrients as they are assimilated from the water column into biomass that is temporarily retained on the benthos and then mineralized and released back into the water column or denitrified. (a) The $\delta^{15} \mathrm{~N}$ of the riverine $\mathrm{NO}_{3}^{-}$reservoir integrates the $\mathrm{NO}_{3}^{-}$and $\mathrm{NH}_{4}^{+}$delivered continually from ground-

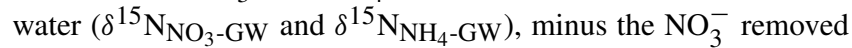
concurrently by sedimentary denitrification - the $\delta^{15} \mathrm{~N}$ of which depends on the sedimentary isotope fractionation communicated to the water column reservoir, ${ }^{15} \varepsilon_{\mathrm{D}}$. Given the small size of the respective $\mathrm{PN}$ and $\mathrm{NH}_{4}^{+}$pools relative to $\mathrm{NO}_{3}^{-}$, ammonification

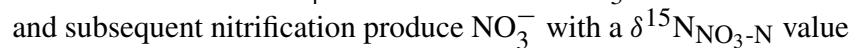
approximating that lost concurrently to assimilation $\left(\delta^{15} \mathrm{~N}_{\mathrm{NO}_{3}}-^{15}\right.$ $\varepsilon_{\mathrm{A}}$ ), notwithstanding the $\mathrm{NH}_{4}^{+}$input from groundwater. The in-

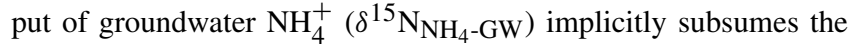
input of reactive allochthonous $\mathrm{PN}$ and DON. (b) The riverine $\delta^{18} \mathrm{O}_{\mathrm{NO}_{3}}$ integrates the $\mathrm{NO}_{3}^{-}$input from groundwater and precipitation $\left(\delta^{18} \mathrm{O}_{\mathrm{NO}_{3}-\mathrm{GW}}\right)$ and from in-river nitrification $\left(\delta^{18} \mathrm{O}_{\mathrm{NO}_{3}-\mathrm{N}}\right)$, minus $\mathrm{NO}_{3}^{-}$lost to algal assimilation and sedimentary denitrification - whose respective values depend on the net isotope effects associated with assimilation and denitrification, ${ }^{18} \varepsilon_{\mathrm{A}}$ and ${ }^{18} \varepsilon_{\mathrm{D}}$.

- although some influence of benthic denitrification on riverine $\delta^{15} \mathrm{~N}_{\mathrm{NO}_{3}}$ values cannot be ruled out. We thus interpret the riverine $\delta^{15} \mathrm{~N}_{\mathrm{NO}_{3}}$ values to predominantly reflect the $\mathrm{N}$ isotope composition of DIN input from the catchment. We return to this insight in a subsequent section, to identify $\mathrm{N}$ sources along the catchment.

\subsection{Influence of in-river biological cycling on $\delta^{18} \mathrm{O}_{\mathrm{NO}_{3}}$ values at low base flow}

The $\delta^{18} \mathrm{O}_{\mathrm{NO}_{3}}$ values along-river can also be interpreted within the framework of nutrient spiraling. As with $\delta^{15} \mathrm{~N}_{\mathrm{NO}_{3}}$, the riverine $\delta^{18} \mathrm{O}_{\mathrm{NO}_{3}}$ values integrate the contribution of
$\mathrm{NO}_{3}^{-}$imported from the catchment (including uncycled atmospheric $\mathrm{NO}_{3}^{-}$), the $\mathrm{NO}_{3}^{-}$produced by nitrification in-river, and the $\mathrm{NO}_{3}^{-}$consumed by assimilation and by denitrification (Fig. 9). Without continual exogenous input from the catchment, $\delta^{18} \mathrm{O}_{\mathrm{NO}_{3}}$ values of an initial $\mathrm{NO}_{3}^{-}$reservoir would theoretically converge downriver onto a steady-state value dictated by the $\delta^{18} \mathrm{O}_{\mathrm{NO}_{3}}$ of newly nitrified $\mathrm{NO}_{3}^{-}$and the effective isotope effect for $\mathrm{NO}_{3}^{-}$consumption, by assimilation and denitrification: for instance, assuming a $\delta^{18} \mathrm{O}_{\mathrm{NO}_{3}}$ value of $-6 \%$ or newly nitrified $\mathrm{NO}_{3}^{-}\left(\delta^{18} \mathrm{O}_{\mathrm{H}_{2} \mathrm{O}}+1 \%\right.$; Casciotti et al., 2008; Sigman et al., 2009; Buchwald and Casciotti, 2010; Granger et al., 2013; Boshers et al., 2019), a canonical $\mathrm{NO}_{3}^{-}$assimilation isotope effect of $5 \%$ o (Needoba et al., 2003), and no influence of sedimentary denitrification on water column $\delta^{18} \mathrm{O}_{\mathrm{NO}_{3}}$, values downriver would asymptote to $-1 \%$. The $\delta^{18} \mathrm{O}_{\mathrm{NO}_{3}}$ values of $2.8 \%$ observed at the bridges during low base flow thus suggest that the $\mathrm{NO}_{3}^{-}$introduced continuously along the catchment had $\delta^{18} \mathrm{O}_{\mathrm{NO}_{3}}$ values greater than $-1 \%$, assuming roughly equivalent in-river assimilation and nitrification fluxes. These greater $\delta^{18} \mathrm{O}_{\mathrm{NO}_{3}}$ values may also signal some influence of sedimentary denitrification in fractionating the water column $\delta^{18} \mathrm{O}_{\mathrm{NO}_{3}}$. Observations of decreasing along-river values are then consistent with the notion of higher catchment $\delta^{18} \mathrm{O}_{\mathrm{NO}_{3}}$ end-member values converging onto lower values determined by the ratio of nitrification to consumption in-river - and associated isotopic fractionation. Within this framework, $\delta^{18} \mathrm{O}_{\mathrm{NO}_{3}}$ values in winter, when biological cycling is dampened, would expectedly increase to values closer to the catchment sources, a prediction that appears to be borne out in our observations. Barnes et al. (2008) similarly observed higher $\delta^{18} \mathrm{O}_{\mathrm{NO}_{3}}$ values during the cold season in streams draining forested watersheds in the northeastern USA. The riverine $\delta^{18} \mathrm{O}_{\mathrm{NO}_{3}}$ values thus afford insights into $\mathrm{N}$ sources and cycling that are consistent with expectations for nutrient spiraling.

\subsubsection{Regional N sources to the Pawcatuck River}

Observations from the along-river surveys provide insights into the contribution of different reaches of the catchment to the riverine $\mathrm{N}$ reservoir. Areas of disproportionate loading can be identified from distinct concentration increases, and areas of lesser loading and/or net attenuation can be identified from concentration decreases. Reaches of the river that exhibit disproportionate loading present potential targets for mitigation. As detailed above, we interpret changes in $\delta^{15} \mathrm{~N}_{\mathrm{NO}_{3}}$ values along-river to primarily reflect differences in the $\delta^{15} \mathrm{~N}$ of DIN inputs from respective reaches of the catchment, thus serving to identify dominant regional $\mathrm{N}$ sources.

Surface water in Worden Pond had relatively low nutrient concentrations, which remained similarly low at Biscuit City Road (Station 2) in two of three samplings. The otherwise extremely elevated $\left[\mathrm{NO}_{3}^{-}\right]$at Station 2 in March 2018 decreased downstream at Station 3 by $>40 \%$, more than can be explained by either dilution from additional inflow or den- 
itrification. This elevated concentration may then reflect the inadvertent sampling of a groundwater plume or a localized reach of slow-flowing water, rather than the mean river composition. Monitoring at Biscuit City Road from 2007-2016 by the Wood-Pawcatuck Watershed Association similarly reveals relatively low median $\left[\mathrm{NO}_{3}^{-}\right]$values of $\sim 1 \mu \mathrm{M}$ during fall samplings, punctuated by stochastic instances of elevated concentrations, as high as $41 \mu \mathrm{M}$ (Fig. S6; Wood-Pawcatuck Watershed Association, 2020). The $\delta^{15} \mathrm{~N}_{\mathrm{NO}_{3}}$ value recorded at this station during the March 2019 sampling was $6.2 \%$ and the $\delta^{18} \mathrm{O}_{\mathrm{NO}_{3}}$ was $4.8 \%$, values consistent with either a groundwater plume or a slow-flowing reach of the river.

Both $\left[\mathrm{NO}_{3}^{-}\right]$and $\left[\mathrm{PO}_{4}^{-}\right]$increased thereafter at Kenyon and Wood River Junction (Stations 3 and 4, respectively) in all sampling campaigns. Associated $\delta^{15} \mathrm{~N}_{\mathrm{NO}_{3}}$ values were relatively low during the March 2019 sampling ( $\leq 4 \%$ ) coincident with more elevated $\left[\mathrm{NO}_{3}^{-}\right]-$potentially signaling the input of DIN by shallow flow from proximate turf farms (Kreitler et al., 1978; Katz et al., 1999; Townsend et al., 2003; Deutsch et al., 2005). Input of uncycled atmospheric $\mathrm{NO}_{3}^{-}$by surface flow due to regional snowmelt, which could also explain lower $\delta^{15} \mathrm{~N}_{\mathrm{NO}_{3}}$ values, is not supported by the corresponding $\delta^{18} \mathrm{O}_{\mathrm{NO}_{3}}$ values, which would otherwise be disproportionately high. Moreover, there was little to no accumulated snow in March 2019. The increased nutrient concentrations observed at Stations 3 and 4 in all sampling campaigns also likely derived in part from the retention ponds at Kenyon Industries, in light of a permitted discharge of $7500 \mathrm{~mol} \mathrm{~N}$ and $950 \mathrm{~mol} P$ per day (US Environmental Protection Agency, 2010). Corresponding $\delta^{15} \mathrm{~N}_{\mathrm{NO}_{3}}$ values at Stations 3 and 4 during the May and November 2018 samplings were $\sim 6 \%$, which could indicate input from deeper agricultural groundwater or could reflect discharge by Kenyon Industries, for which we do not have endmember values.

Inflow from the less impacted Wood River evidently diluted nutrient concentrations in the Pawcatuck River (Station 7). The Wood River contributes significantly to the total discharge of the Pawcatuck River ( $\geq 14 \pm 5 \%$ of total - based on discharge at Hope Valley USGS gauge), draining a more forested watershed that harbors fewer agricultural areas than the lower Pawcatuck River. The $\left[\mathrm{NO}_{3}^{-}\right]$in all sampling campaigns remained relatively invariant downstream of the Wood River inflow through the largely forested catchment to Potter Hill Dam (Station 11), while $\delta^{15} \mathrm{~N}_{\mathrm{NO}_{3}}$ values increased marginally. The increases in $\left[\mathrm{NO}_{3}^{-}\right]$and $\delta^{15} \mathrm{~N}_{\mathrm{NO}_{3}}$ thereafter to the Stillman and Westerly bridges indicate DIN input from groundwater in the more populated portion of the watershed. The population density and associated septic systems increase considerably in the vicinity of the town of Westerly (Wood-Pawcatuck Watershed Association, 2016). Septic leachate and urban runoff are typically associated with relatively higher $\delta^{15} \mathrm{~N}$ values, on the order of $8 \%$ to $15 \%$ (Kendall et al., 2007; Böhlke et al., 2009; Kasper et al., 2015). Thus, changes in land use along the catchment best explain the $\delta^{15} \mathrm{~N}_{\mathrm{NO}_{3}}$ increase in the lower portion of the river.

In all, the substantial difference in [DIN] between Stations 2 and 5 signals disproportionate input from this section of the watershed, likely owing to the proximity of turf farms and discharge from Kenyon Industries. Indeed, the riverine DIN flux at Wood River Junction amounted to $28 \pm 11 \%$ of the DIN flux recorded at the Stillman bridge among the three sampling dates, while accounting for only $11 \pm 2 \%$ of the riverine discharge. A fraction of the $\mathrm{N}$ loaded in this portion of the river may arguably be partially attenuated by denitrification along-river; nevertheless, this regional input remains substantial even assuming some biological attenuation. This portion of the river also contributed disproportionately to the riverine $\mathrm{PO}_{4}^{3-}$ burden, although we do not explicitly consider this contribution in relation to the total discharge into the estuary, given the complex geochemistry of $\mathrm{PO}_{4}^{3--}$ that involves adsorption and release from authigenic particles in sediments (Froelich, 1988).

The increase in [DIN] and $\delta^{15} \mathrm{~N}_{\mathrm{NO}_{3}}$ values in the lower portion of the river, in light of the large coincident river discharge, also signals a disproportionate contribution from the urbanized portion of the catchment. However, lacking estimates of river discharge at Potter Hill Dam (Station 11), we cannot deduce the fractional contribution from this portion of the watershed confidently. Nevertheless, assuming a $\delta^{15} \mathrm{~N}$ input from the urbanized catchment of $10 \%$ and a mean $\delta^{15} \mathrm{~N}_{\mathrm{NO}_{3}}$ of $6 \%$ at Potter Hill Dam, compared to $8 \%$ at the Westerly Bridge, the DIN added to the river within this reach would amount to $\sim 50 \%$ of the total riverine $\mathrm{N}$ load. Otherwise, assuming a $\delta^{15} \mathrm{~N}$ input of $15 \%$, the DIN contributed from the urbanized reach would otherwise amount to $\sim 20 \%$ of the total.

\subsection{N loading into Little Narragansett Bay}

\subsubsection{Riverine contributions}

Estimates of the annual N loading from the Pawcatuck River into Little Narragansett Bay for 2018, compiled from our weekly measurements at the Stillman Bridge, were $20.2 \times$ $10^{6} \mathrm{~mol} \mathrm{yr}^{-1}$ for DIN and $40.3 \times 10^{6} \mathrm{~mol} \mathrm{yr}^{-1}$ for TN, albeit with uncertainty associated with the TN loading estimate given the variability of our DON measurements (Table 2). These values are considerably larger than those estimated from biweekly measurements at the Stillman Bridge for 2002 by Fulweiler and Nixon (2005), which were $7.2 \times$ $10^{6} \mathrm{~mol} \mathrm{yr}^{-1}$ for DIN and $16.0 \times 10^{6} \mathrm{~mol} \mathrm{yr}^{-1}$ for TN. The greater $\mathrm{N}$ loading in 2018 could arise from (a) an increase in groundwater concentrations and/or point source discharge, evident at low base flow, and/or (b) increased $\mathrm{N}$ loading by shallow flow. The latter could result from increased atmospheric $\mathrm{N}$ deposition, greater annual precipitation, and/or higher surface $\mathrm{N}$ concentrations imported by shallow flow. We examine these hypotheses in turn. 
In 2002, the [DIN] at low base flow, which reflects that associated with deeper groundwater and point source discharge, was $\sim 50 \mu \mathrm{M}$ (Fulweiler and Nixon, 2005) - thus lower than the value of $\sim 64 \mu \mathrm{M}$ observed by us - suggesting lower DIN inputs from deeper groundwater and/or point sources in 2002. This inference is supported by monitoring data of the Wood-Pawcatuck Watershed Association from 1989 to 2017, which documented a discernible increase in riverine $\left[\mathrm{NO}_{3}^{-}\right]$of approximately $1 \mu \mathrm{M}$ per year at Bradford (Station 8) in the month of October and a slighter rate of increase $0.3 \mu \mathrm{M}$ per year in May (Fig. S7a). These trends are not explained by a secular change in monthly precipitation (Fig. S7b). Given that mean river discharge is generally higher in May than in October, the greater rate of increase in October suggests an increase in [DIN] of deeper groundwater entering the river - and/or an increase in point source discharge up-river. Assuming a $10 \mu \mathrm{M}$ difference in [DIN] during low base flow at the Stillman Bridge in 2018 compared to 2002, and a year-round discharge of deeper groundwater of $0.25 \times 10^{6} \mathrm{~m}^{3} \mathrm{~d}^{-1}$ (based on the mean low-base-flow discharge), $0.9 \times 10^{6} \mathrm{~mol}$ of additional DIN was potentially delivered in 2018 from the increased groundwater or point source [DIN]. This greater DIN input from deeper groundwater and/or point sources only explains a small fraction of the additional loading of $12.9 \times 10^{6} \mathrm{~mol}$ DIN estimated for 2018 compared to 2002.

Regional atmospheric deposition of DIN has decreased $\sim 67 \%$ since 2000 , from $\sim 95$ to $36 \mu \mathrm{M}$ DIN in 2018 (NOAA National Atmospheric Deposition Program, 2019), which should have resulted in a lower riverine $\mathrm{N}$ flux given similar annual precipitation. However, 2002 was a drought year, whereas 2018 was the third wettest year on record in Washington County, RI, with total precipitation at $152 \mathrm{~cm}$ compared to an 80-year mean of $114 \mathrm{~cm}$ (NOAA National Centers for Environmental information, 2019). River discharge was thus substantially lower in 2002 , at $303 \times 10^{6} \mathrm{~m}^{3} \mathrm{yr}^{-1}$, compared to $702 \times 10^{6} \mathrm{~m}^{3} \mathrm{yr}^{-1}$ in 2018 (Table 2). The larger riverine $\mathrm{N}$ loading in 2018 is thus explained by greater precipitation and consequent discharge above low base flow, importing additional DIN (and DON) into the river via shallow flow. Assuming a comparable [DIN] delivered by shallow flow between then and now $\left(26 \pm 3 \mu \mathrm{mol} \mathrm{L}^{-1}\right)$, the greater discharge in 2018 entails an additional DIN influx of 10.1 $( \pm 1.2) \times 10^{6} \mathrm{~mol} \mathrm{yr}^{-1}$, accounting for most of the estimated difference of $12.9 \times 10^{6} \mathrm{molDIN} \mathrm{yr}^{-1}$ between 2018 and 2002. The greater discharge in 2018 ostensibly resulted in increased DON influx into the river, although the variability of our DON measurements precludes a robust estimate of this additional flux.

In all, the greater DIN loading in 2018 compared to 2002 is explained in small part by an apparent increase in [DIN] at low base flow - deriving from a parallel increase in groundwater [DIN] or a potential increase in point source discharge by Kenyon Industries - and in greater part by a substantial difference in annual river discharge and associated im- port of DIN (and DON). Parenthetically, Eq. (4) returns a load of $10.1 \times 10^{6} \mathrm{molDIN} \mathrm{yr}^{-1}$ for 2002 when adjusting low base flow to $50 \mu \mathrm{M}$, compared to the observed flux of $7.2 \times 10^{6} \mathrm{molDIN} \mathrm{yr}^{-1}$ (Fulweiler and Nixon, 2005), suggesting that the import of DIN from shallow groundwater may also have increased in the last 2 decades.

Extrapolating DIN discharge for other years with various river flows allows for a comparison to independent estimates of nitrogen loads from the watershed. Vaudrey et al. (2017) utilized a land use model to estimate the TN load from the Pawcatuck River at $14.6 \times 10^{6} \mathrm{~mol} \mathrm{TN} \mathrm{yr}^{-1}$, based on precipitation from 2013-2015. In comparison, using the mixing curve algorithm (Eq. 4) and river flow for the 2013-2015 period, and further assuming that DIN accounted for roughly half of TN as in our measurements, DIN loading is otherwise estimated as $13.7 \times 10^{6} \mathrm{~mol} \mathrm{DIN} \mathrm{yr}^{-1}$ and TN loading as $27.3 \times 10^{6} \mathrm{~mol} \mathrm{TN} \mathrm{yr}^{-1}$ for this period (Table 2). The TN load thus estimated is $12.7 \times 10^{6} \mathrm{~mol} \mathrm{TN} \mathrm{yr}^{-1}$ higher than the land use model estimate, leaving nearly $45 \%$ of $\mathrm{TN}$ apparently unaccounted for. However, our TN measurements include both labile and non-labile $\mathrm{N}$, while the land use model represents reactive $\mathrm{TN}$ and does not account for non-labile species. On the basis that refractory humified allochthonous organic material dominates the DON pool in the Pawcatuck River - an N pool that is largely unavailable to micro-organisms (Stevenson 1994) - a value of $45 \%$ of TN being non-labile could be consistent with this system. Seitzinger et al. (1997) otherwise estimated that 40\%-70\% of DON from the Delaware River was reactive on pertinent timescales. The data at hand do not permit us to resolve this quandary, although characterizing the reactivity of DON from the Pawcatuck River is evidently crucial to mitigating eutrophication in the bay.

Rhode Island met an ambitious goal of a $50 \%$ reduction in N loading to Narragansett Bay in 2012 relative to 1995-1996 loads, but the Pawcatuck River was not included in these reduction priorities. This oversight is evident in the loads we currently see to the Pawcatuck River relative to loads in rivers draining to Narragansett Bay, located just east of the Pawcatuck River watershed. In the early 1980s through the early 2000 s, the TN load normalized to watershed area for these rivers ranged from 9.3 to $14.9 \mathrm{~kg} \mathrm{ha}^{-1} \mathrm{yr}^{-1}$ (as reviewed in Narragansett Bay Estuary Program, 2017; Nixon et al., 1995, 2008). Compared to this time period, the Pawcatuck River's current load of $7.4 \mathrm{~kg} \mathrm{~N} \mathrm{ha}^{-1} \mathrm{yr}^{-1}$ is relatively low. However, these riverine loads were substantially reduced, achieving an average of $4.8 \mathrm{~kg} \mathrm{ha}^{-1} \mathrm{yr}^{-1}$ in recent $\mathrm{N}$ budgets developed for the 2013-2015 time period, with one exception (i.e., the Ten Mile River; Narragansett Bay Estuary Program, 2017; Krumholz, 2012). Export from pristine temperate zones prior to human disturbances is estimated to have been on the order of $1.3 \mathrm{~kg} \mathrm{~N} \mathrm{ha}^{-1} \mathrm{yr}^{-1}$ (Howarth et al., 1995, 1996). Most Narragansett Bay rivers are moving toward this pristine condition, whereas the Pawcatuck River has shown an increase in $\mathrm{N}$ load over time. 


\subsubsection{Point source loading from the WWTFs and Kenyon Industries}

The Westerly and Pawcatuck WWTFs downstream of the Stillman and Westerly bridges accounted for a relatively modest fraction of the total annual nitrogen loading into the estuary, approximately $7 \%$ (Table 2). This estimate does not consider loading from the catchment downstream of the Stillman and Westerly bridges, which would modestly lower the relative contributions of the WWTFs. Fulweiler and Nixon (2005) otherwise estimated that the WWTFs accounted for $18 \%$ of annual $\mathrm{N}$ loading into the estuary, albeit relying on a WWTF loading estimate of $6 \times 10^{6} \mathrm{~mol} \mathrm{TN} \mathrm{yr}^{-1}$, a flux notably higher than that of $1.45 \times 10^{6} \mathrm{~mol} \mathrm{TN} \mathrm{yr}^{-1}$ reported by the Rhode Island Department of Environmental Management and the Connecticut Department of Energy and Environmental Protection for 2002 (Vaudrey et al., 2017). Replacing the higher WWTF load in the Fulweiler and Nixon (2005) estimate with the lower load reported by the states yields a match to the current study, indicating that the WWTFs accounted for about $5 \%$ of the total annual load. Independent estimates by Vaudrey et al. (2017) derived from a land use model suggest that WWTF effluents contribute $\sim 13 \%$ of the riverine-plusWWTF TN discharged to the estuary on an annual basis, but this load included only reactive nitrogen and did not estimate the non-labile fraction measured in this and the Fulweiler and Nixon (2005) study; including an estimate of the non-labile fraction brings the annual contribution from WWTFs down to $8 \%$ of the $\mathrm{TN}$.

The annual $\mathrm{N}$ loading into the Pawcatuck River from Kenyon Industries, as monitored by the Rhode Island Department of Environmental Monitoring from 2011-2013, was $2.7 \times 10^{6} \mathrm{~mol} \mathrm{TN} \mathrm{yr}^{-1}$, thus accounting for $6 \%$ of the annual riverine-plus-WWTF loading to the estuary, an input comparable to that of the WWTFs (Table 2). Loading by Kenyon Industries is notable in that it is approximately equivalent to the amount of fertilizer applied to agricultural, hay, and pasture lands throughout the whole watershed (Vaudrey et al., 2017).

The overgrowth of nuisance macroalgae in Little Narragansett Bay is presumably fueled predominantly by nutrients delivered during warmer months, at which time riverine $\mathrm{N}$ loading is at a relative minimum (Table 2). While the fraction of TN loading to the estuary by the WWTFs was negligible during colder months $(<5 \%)$, this proportion increased to $21 \%$ during the warmer months in 2018, from 1 May to 31 October. The estimated contribution from Kenyon Industries similarly increased to $16 \%$ of total $\mathrm{N}$ loading during the warmer months. The influence of these point sources on algal growth during the warm season is likely to be even greater, considering that an important fraction of the total $\mathrm{N}$ flux from the Pawcatuck River derived from DON (38\% from May to November), of which only a fraction may be bioavailable on pertinent timescales. Assuming a median reactivity of river- ine DON of $50 \%$ (Seitzinger et al., 1997), the WWTFs and Kenyon industries could account for as much as $25 \%$ and $19 \%$ of labile $\mathrm{N}$ loading to the estuary during the warm season, respectively, given a riverine DIN loading of $2.6 \times 10^{6}$ mol N NIN from May through October. Thus, we estimate that the WWTFs contributed between $21 \%-25 \%$ of $\mathrm{N}$ loading to the estuary during the warm season, and Kenyon Industries contributed $16 \%-19 \%$.

\subsection{Implications for the mitigation of eutrophication}

Our analysis suggests that the Pawcatuck River is strongly impacted by anthropogenic $\mathrm{N}$ input. Compounding the problem, the drainage basin of the river is large relative to the receiving estuary, explaining the severe eutrophication therein. The DIN concentrations and $\mathrm{NO}_{3}^{-}$isotope ratios indicate substantive inputs of reactive $\mathrm{N}$ to the river from agricultural and/or point sources along the upper river catchment and from urbanized sources along the lower reach of the river. The reactive $\mathrm{N}$ loaded annually into Little Narragansett Bay from the Pawcatuck River is highly influenced by the amplitude of river discharge, increasing with discharge due to the additional import of reactive $\mathrm{N}$ by shallow flow. Loading during the warmer months in 2018 was thus substantially lower than in colder months due to lower summertime precipitation, rendering point source discharges from Kenyon Industries and WWTFs more important to the total $\mathrm{N}$ loading to the estuary during the major growing season.

Reductions in summertime discharge by Kenyon Industries and the Westerly WWTF offer the most expeditious targets to decrease $\mathrm{N}$ loading into the estuary, albeit at considerable cost. The disproportionate loading from the catchment of the upper river also begs more tempered applications of agricultural fertilizers at adjacent turf farms and expansion of riparian buffers, in order to affect reductions in shallow and deeper groundwater $\mathrm{N}$ concentrations. In the more populated portion of the watershed, $\mathrm{N}$ reductions could be achieved by augmenting linkage of households to the sewer line, transitioning traditional septic systems to advanced, N-removing septic systems and encouraging the dismantling of outdated, legacy cesspools (Amador et al., 2017; Narragansett Bay Estuary Program, 2017). Within the watershed draining directly to the estuarine portion of the Pawcatuck River south of the Westerly Bridge, $90 \%$ of the households are connected to sewer (Vaudrey et al., 2017). In the remainder of the watershed, where groundwater drains to a freshwater body (wetland, pond, river) prior to entering the estuary, only $21 \%$ of people are connected to sewer. This distribution reflects the urban nature of the watershed near the coast and the more rural character of the watershed further inland. Finally, restricting the use of lawn fertilizers and lessening the extent of impervious surfaces in and around Westerly would further aid in reducing loading from storm water.

While reductions in $\mathrm{N}$ loading are necessary to mitigate eutrophication in Little Narragansett Bay, target $\mathrm{N}$ loads have 
yet to be adopted by Rhode Island or Connecticut. A TN load of $50 \mathrm{~kg} \mathrm{ha}_{\text {estuary }}^{-1} \mathrm{yr}^{-1}\left(3.6 \times 10^{3} \mathrm{~mol} \mathrm{ha}_{\text {estuary }}^{-1} \mathrm{yr}^{-1}\right)$, which is generally supportive of eelgrass, has been proposed by the scientific community (Hauxwell et al., 2003; Latimer and Rego, 2010). In 2018, the DIN and TN loads to Little Narragansett Bay were $37 \times 10^{3}$ and $74 \times 10^{3} \mathrm{~mol} \mathrm{~N} \mathrm{ha}^{-1} \mathrm{yr}^{-1}$, respectively (given a 583 ha area of estuary downstream of the Westerly Bridge), suggesting that an astounding 10 to 20fold reduction in $\mathrm{N}$ loading may be required to recover eelgrass beds. We consider that a fraction of this $\mathrm{N}$ load may escape the estuary directly and not be retained therein, reducing the effective annual estuarine $\mathrm{N}$ load. Moreover, seasonality of nitrogen delivery coupled with the warm summer growing season may point the way towards targeted summer reductions that could have a greater impact on the eutrophic status of the system. Regardless, immediate mitigation efforts are necessary at this junction, not purely to realize reductions in $\mathrm{N}$ loading but, more soberly, to prevent further increases in $\mathrm{N}$ loading to the Pawcatuck River and continuing degradation of the river and estuary.

\section{Conclusions}

Our findings illustrate the utility of $\mathrm{NO}_{3}^{-}$isotopologue ratios in differentiating among $\mathrm{N}$ sources, with implications for the management of $\mathrm{N}$ loading of the watershed. In particular, the seasonal and flow-dependent nature of $\mathrm{N}$ loading and cycling uncovered herein presents important considerations for mitigation efforts.

Our interpretations of $\mathrm{NO}_{3}^{-}$isotopologue dynamics also move beyond the traditional source attribution framework in an effort to reconcile with the current theory of riverine $\mathrm{N}$ biogeochemistry. Nutrient spiraling theory offers a powerful conceptual basis to differentiate the influences of $\mathrm{N}$ sources vs. cycling on $\mathrm{NO}_{3}^{-}$isotopologue distributions. Continued inquiry in the context of this framework is bound to yield novel and unexpected insights into $\mathrm{N}$ isotopologue cycling and, more fundamentally, into river biogeochemistry.

Data availability. All data were submitted to Rhode Island Department of Environmental Management and the Connecticut Department of Energy and Environmental Protection and are submitted to the PANGAEA data repository https://doi.org/10.1594/PANGAEA.931561 (Rollinson et al., 2021).

Supplement. The supplement related to this article is available online at: https://doi.org/10.5194/bg-18-3421-2021-supplement.

Author contributions. VRR and JG conceive the research question, designed the study approach, led the field survey, ensured data curation, and conducted formal analysis. SCC, MLB, CPK, LAT, and
HCW assisted with data collection and analysis. CMM assisted with statistical analyses. CRT and MGH provided use of specialized facilities. JG and JMPV secured funding for the investigation. VRR and JG wrote the first draft of the paper, and all co-authors contributed to writing review and editing.

Competing interests. The authors declare that they have no conflict of interest.

Acknowledgements. We thank Clare Schlink, Reide Jacksin, Lindsey Potts, Danielle Boshers-Snow, Anna Alvarado, Peter Ruffino, and Matt Lacerra for assistance with fieldwork and/or laboratory analyses. We are also grateful to Nicholas De Gemmis and the Jacobs Group at Westerly Wastewater Treatment facility for providing us with weekly samples. Water quality monitoring by the Wood-Pawcatuck Watershed Association provided important historical data that facilitated our interpretations. Monitoring of water quality in Little Narragansett Bay by Clean Up Sound and Harbors (CUSH) inspired our effort to determine sources of nutrients to the estuary. Comments by the two anonymous reviewers helped improve the manuscript.

Financial support. This research has been supported by the NOAA Connecticut Sea Grant, University of Connecticut (grant no. NA18OAR4170081 project number R/ER-30) and the NSF Career Award (grant no. OCE-1554474).

Review statement. This paper was edited by Jack Middelburg and reviewed by two anonymous referees.

\section{References}

4500- $\mathrm{NH}_{3}$ NITROGEN (AMMONIA), Standard Methods For the Examination of Water and Wastewater, https://doi.org/10.2105/SMWW.2882.087, 2018.

4500-NO ${ }_{2}^{-}$NITROGEN (NITRITE), Standard Methods For the Examination of Water and Wastewater, https://doi.org/10.2105/SMWW.2882.088, 2018.

4500-NO $\mathrm{NO}_{3}$ NITROGEN (NITRATE), Standard Methods For the Examination of Water and Wastewater, https://doi.org/10.2105/SMWW.2882.089, 2018.

4500-P PHOSPHORUS, Standard Methods For the Examination of Water and Wastewater, https://doi.org/10.2105/SMWW.2882.093, 2018.

Amundson, R., Austin, A. T., Schuur, E. A. G., Yoo, K., Matzek, V., Kendall, C., Uebersax, A., Brenner, D., and Baisden, W. T.: Global patterns of the isotopic composition of soil and plant nitrogen, Global Biogeochem. Cy., 17, https://doi.org/10.1029/2002GB001903, 2003.

Andersson, K. K. and Hooper, A. B.: $\mathrm{O}_{2}$ and $\mathrm{H}_{2} \mathrm{O}$ are each the source of one $\mathrm{O}$ in $\mathrm{NO}_{2}$ produced from $\mathrm{NH}_{3}$ by Nitrosomonas: 15N-NMR evidence, FEBS Lett., 164, 236-240, 1983. 
Arar, E. and Collins, G.: In vitro determination of Chlorophyll a and pheophytin in marine freshwater and algae by fluoresecence, National Exposure Research Laboratory, Cincinnatri, USA, 22 pp., 1997.

Barnes, R. T. and Raymond, P.: The contribution of agricultural and urban activities to inorganic carbon fluxes within temperate watersheds, Chem. Geol., 266, 318-327, 2009.

Barnes, R. T., Raymond, P. A., and Casciotti, K. L.: Dual isotope analyses indicate efficient processing of atmospheric nitrate by forested watersheds in the northeastern U.S, Biogeochemistry, 90, 15-27, 2008.

Baron, J. S., Hall, E. K., Nolan, B. T., Finlay, J. C., Bernhardt, E. S., Harrison, J. A., Chan, F., and Boyer, E. W.: The interactive effects of excess reactive nitrogen and climate change on aquatic ecosystems and water resources of the United States, Biogeochemistry, 114, 71-92, 2013.

Beale, B. M. L.: Some uses of computers in operational research, Industrielle Organisation, 31, 27-28, 1962.

Berezina, N. and Golubkov, S.: Effect of drifting macroalgae Cladophora glomerata on benthic community dynamics in the easternmost Baltic Sea, J. Mar. Syst., 74, S80-S85, https://doi.org/10.1016/j.jmarsys.2008.03.027, 2008.

Böhlke, J. K.: Sources, transport, and reaction of nitrate in ground water, Residence times and nitrate transport in ground water discharging to streams in the Chesapeake Bay Watershed, US Geological Survey Water-Resources Investigations Report 03-4035, US Geological Survey, New Cumberland, Pennsylvania, USA, 215 pp., 2003.

Böhlke, J. K., Smith, R. L., and Miller, D. N.: Ammonium transport and reaction in contaminated groundwater: Application of isotope tracers and isotope fractionation studies, Water Resour. Res., 42, W05411, https://doi.org/10.1029/2005WR004349, 2006.

Böhlke, J. K., Hatzinger, P. B., Sturchio, N. C., Gu, B., Abbene, I., and Mroczkowski, S. J.: Atacama Perchlorate as an Agricultural Contaminant in Groundwater: Isotopic and Chronologic Evidence from Long Island, New York, Environ. Sci. Technol., 43, 5619-5625, 2009.

Boshers, D. S., Granger, J., Tobias, C. R., Böhlke, J. K., and Smith, R. L.: Constraining the Oxygen Isotopic Composition of Nitrate Produced by Nitrification, Environ. Sci. Technol., 53, 12061216, 2019.

Braman, R. S. and Hendrix, S. A.: Nanogram nitrite and nitrate determination in environmental and biological materials by vanadium (III) reduction with chemiluminescence detection, Anal. Chem., 61, 2715-2718, 1989.

Brandes, J. A. and Devol, A. H.: Isotopic fractionation of oxygen and nitrogen in coastal marine sediments, Geochim. Cosmochim. Ac., 61, 1793-1801, https://doi.org/10.1016/S00167037(97)00041-0, 1997.

Brookshire, E. N. J., Valett, H. M., Thomas, S. A., and Webster, J. R.: Coupled cycling of dissolved organic nitrogen and carbon in a forest stream, Ecology, 86, 2487-2496, 2005.

Buchwald, C. and Casciotti, K. L.: Oxygen isotopic fractionation and exchange during bacterial nitrite oxidation, Limnol. Oceanogr., 55, 1064-1074, 2010.

Casciotti, K., Trull, T. W., Glover, D. M., and Davies, D.: Constraints on nitrogen cycling in the subtropical North $\mathrm{Pa}$ cific Station ALOHA from isotopic measurements of ni- trate and particulate nitrogen, Deep Sea Res., 55, 1661, https://doi.org/10.1016/j.dsr2.2008.04.017, 2008.

Casciotti, K. L.: Nitrogen and Oxygen Isotopic Studies of the Marine Nitrogen Cycle, Annu. Rev. Mar. Sci., 8, 379-407, 2016.

Casciotti, K. L., Sigman, D. M., Hastings, M. G., Böhlke, J. K., and Hilkert, A.: Measurement of the oxygen isotopic composition of nitrate in seawater and freshwater using the denitrifier method, Anal. Chem., 74, 4905, https://doi.org/10.1021/ac020113w, 2002.

D’Avanzo, C. and Kremer, J. N.: Diel oxygen dynamics and anoxic events in an eutrophic estuary of Waquoit Bay, Massachusetts, Estuaries, 17, 131-139, 1994.

Deutsch, B., Liskow, I., Kahle, P., and Voss, M.: Variations in the $\delta^{15} \mathrm{~N}$ and $\delta^{18} \mathrm{O}$ values of nitrate in drainage water of two fertilized fields in Mecklenburg-Vorpommern (Germany), Aquat. Sci., 67, 156-165, 2005.

Dickerman, D. C. and Bell, R. W.: Hydrogeology, Water Quality, and Ground-water-development Alternatives in the Lower Wood River Ground-water Reservoir, Rhode Island, US Department of the Interior, US Geological Survey, Providence, Rhode Island, USA, 92 pp., 1993.

Dickerman, D., Bell, R., Mulvey, K., Peterman, E., and Russell, J.: Geohydrologic data for the upper Wood River ground-water reservoir, Rhode Island, Rhode Island Water Resources Board Water Information Series Report, Providence, RI, USA, 274 pp., 1989.

Dillingham, T. P.: The Pawcatuck River Estuary and Little Narragansett Bay: An Interstate Management Plan: Adopted July 14, 1992, Rhode Island Coastal Resources Management Council Connecticut Department of Environmental Protection Stonington, Connecticut and Westerly Rhode Island, 1993.

Divers, M., Elliott, E., and Bain, D.: Quantification of Nitrate Sources to an Urban Stream Using Dual Nitrate Isotopes, Environ. Sci. Technol., 48, 10580-7, https://doi.org/10.1021/es404880j, 2014.

Dodds, W. K. and Gudder, D. A.: The Ecology Of Cladophora, J. Phycol., 28, 415-427, 1992.

Dubrovsky, N. M., Burow, K. R., Clark, G. M., Gronberg, J. M., Hamilton, P. A., Hitt, K. J., Mueller, D. K., Munn, M. D., Nolan, B. T., Puckett, L. J., Rupert, M. G., Short, T. M., Spahr, N. E., Sprague, L. A., and Wilber, W. G.: The quality of our Nation's waters - Nutrients in the Nation's streams and groundwater, 1992-2004, US Geological Survey Circular 1350, available at: http://water.usgs.gov/nawqa/nutrients/pubs/circ1350 (last access: 9 March 2020), 2010.

Elwood, J. W. and Turner, R. R.: Streams: Water Chemistry and Ecology, in: Analysis of Biogeochemical Cycling Processes in Walker Branch Watershed, edited by: Johnson, D. W. and Van Hook, R. I., Springer, New York, USA, 301-350, 1989.

Ensign, S. H. and Doyle, M. W.: Nutrient spiraling in streams and river networks, J. Geophys. Res., 111, G04009, https://doi.org/10.1029/2005JG000114, 2006.

Fang, Y., Koba, K., Makabe, A., Zhu, F., Fan, S., and Yoh, M.: Low $\delta^{18} \mathrm{O}$ Values of Nitrate Produced from Nitrification in Temperate Forest Soils, Environ. Sci. Technol., 46, 8723-8730, 2012.

Froelich, P. N.: Kinetic control of dissolved phosphate in natural rivers and estuaries: A primer on the phosphate buffer mechanism, Limnol. Oceanogr., 33, 649-668, 1988. 
Fulweiler, R. W. and Nixon, S. W.: Export of Nitrogen, Phosphorus, and Suspended Solids from a Southern New England Watershed to Little Narragansett Bay, Biogeochemistry, 76, 567-593, 2005.

Garside, C.: A chemiluminescent technique for the determination of nanomolar concentrations of nitrate and nitrite in seawater, Mar. Chem., 11, 159-167, 1982.

Granger, J. and Wankel, S. D.: Isotopic overprinting of nitrification on denitrification as a ubiquitous and unifying feature of environmental nitrogen cycling, P. Natl. Acad. Sci. USA, 113, 63916400, https://doi.org/10.1073/pnas.1601383113, 2016.

Granger, J., Sigman, D. M., Needoba, J. A., and Harrison, P. J.: Coupled nitrogen and oxygen isotope fractionation of nitrate during assimilation by cultures of marine phytoplankton, Limnol. Oceanogr., 49, 1763-1773, 2004.

Granger, J., Prokopenko, M. G., Sigman, D. M., Mordy, C. W., Morse, Z. M., Morales, L. V., Sambrotto, R. N., and Plessen, B.: Coupled nitrification-denitrification in sediment of the eastern Bering Sea shelf leads to ${ }^{15} \mathrm{~N}$ enrichment of fixed $\mathrm{N}$ in shelf waters, J. Geophys. Res., 116, C11006, https://doi.org/10.1029/2010JC006751, 2011.

Granger, J., Prokopenko, M. G., Mordy, C. W., and Sigman, D. M.: The proportion of remineralized nitrate on the ice-covered eastern Bering Sea shelf evidenced from the oxygen isotope ratio of nitrate, Global Biogeochem. Cy., 27, 962-971, 2013.

Grasshoff, K., Kremling, K., and Ehrhardt, M.: Methods of Seawater Analysis, Third Edition, Wiley, New York, USA, https://doi.org/10.1002/9783527613984, 1999.

Green, C. T., Fisher, L. H., and Bekins, B. A.: Nitrogen Fluxes through Unsaturated Zones in Five Agricultural Settings across the United States, J. Environ. Qual., 37, 1073-1085, 2008.

Gruber, N. and Galloway, J. N.: An Earth-system perspective of the global nitrogen cycle, Nature, 451, 293-296, https://doi.org/10.1038/nature06592, 2008.

Harvey, J. W., Böhlke, J. K., Voytek, M. A., Scott, D., and Tobias, C. R.: Hyporheic zone denitrification: Controls on effective reaction depth and contribution to whole-stream mass balance, Water Resour. Res., 49, 6298-6316, 2013.

Hauxwell, J., Cebrian, J., and Valiela, I.: Eelgrass Zostera marina loss in temperate estuaries: Relationship to land-derived nitrogen loads and effect of light limitation imposed by algae, Mar. Ecol. Prog. Ser., 247, 59-73, 2003.

Hedin, L. O., von Fischer, J. C., Ostrom, N. E., Kennedy, B. P., Brown, M. G., and Robertson, G. P.: Thermodynamic constraints on nitrogentransformations and other biogeochemicalprocesses at soil-stream interfaces, Ecology, 79, 684-703, 1998.

Heisler, J. P., Glibert, P., Burkholder, J., Anderson, D., Cochlan, W., Dennison, W., Dortch, Q., Gobler, C., Heil, C., Humphries, E., Lewitus, A., Magnien, R., Marshall, H., Sellner, K., Stockwell, D. A., Stoecker, D., and Suddleson, M.: Eutrophication and Harmful Algal Blooms: A Scientific Consensus, Harmful Algae, 8, 3-13, 2008.

Hendry, M. J., McCready, R. G. L., and Gould, W. D.: Distribution, source and evolution of nitrate in a glacial till of southern Alberta, Canada, J. Hydrol., 70, 177-198, https://doi.org/10.1016/0022-1694(84)90121-5, 1984.

Hinkle, S. R., Böhlke, J. K., and Fisher, L. H.: Mass balance and isotope effects during nitrogen transport through septic tank systems with packed-bed (sand) filters, Sci. Total Environ., 407, 324-332, https://doi.org/10.1016/j.scitotenv.2008.08.036, 2008.
Hollocher, T. C.: Source of the oxygen atoms of nitrate in the oxidation of nitrite by Nitrobacter agilis and evidence against a P$\mathrm{O}-\mathrm{N}$ anhydride mechanism in oxidative phosphorylation, Arch. Biochem. Biophys., 233, 721-727, https://doi.org/10.1016/00039861(84)90499-5, 1984.

Holloway, J., Dahlgren, R., Hansen, B., and Casey, W.: Contribution of bedrock nitrogen to high nitrate concentrations in stream water, Nature, 395, 785-788, 1998.

Houlton, B. Z. and Bai, E.: Imprint of denitrifying bacteria on the global terrestrial biosphere, P. Natl. Acad. Sci. USA, 106, 21713, https://doi.org/10.1073/pnas.0912111106, 2009.

Houlton, B. Z., Sigman, D. M., and Hedin, L. O.: Isotopic evidence for large gaseous nitrogen losses from tropical rainforests, P. Natl. Acad. Sci. USA, 103, 8745-8750, https://doi.org/10.1073/pnas.0510185103, 2006.

Howarth, R. W., Jensen, H. S., Marina, R., and Postma, H.: Transport to and processing of $\mathrm{P}$ in near-shore and oceanic waters, in: Phosphorus in the global environment, John Wiley \& Sons Ltd, Chichester, UK, 323-346, 1995.

Howarth, R. W., Billen, G., Swaney, D., Townsend, A., Jaworski, N., Lajtha, K., Downing, J. A., Elmgren, R., Caraco, N., Jordan, T., Berendse, F., Freney, J., Kudeyarov, V., Murdoch, P., and Zhao-Liang, Z.: Regional nitrogen budgets and riverine $\mathrm{N}$ and $\mathrm{P}$ fluxes for the drainages to the North Atlantic Ocean: Natural and human influences, Biogeochemistry, 35, 75-139, 1996.

Johannsen, A., Dähnke, K., and Emeis, K.: Isotopic composition of nitrate in five German rivers discharging into the North Sea, Org. Geochem., 39, 1678-1689, 2008.

Kaiser, J., Hastings, M. G., Houlton, B. Z., Röckmann, T., and Sigman, D. M.: Triple Oxygen Isotope Analysis of Nitrate Using the Denitrifier Method and Thermal Decomposition of $\mathrm{N}_{2} \mathrm{O}$, Anal. Chem., 79, 599-607, 2007.

Kasper, J. W., Denver, J. M., and York, J. K.: Suburban Groundwater Quality as Influenced by Turfgrass and Septic Sources, Delmarva Peninsula, USA, J. Environ. Qual., 44, 642-654, 2015.

Katz, B., Hornsby, H., Bohlke, J., and Mokray, M.: Sources and Chronology of Nitrate Contamination in Spring Waters, Suwannee River Basin, Florida, Water-Resources Investigations Report 99-4252, US Geological Survey, Tallahassee, USA, 59 pp., https://doi.org/10.3133/wri994252, 1999.

Keeling, C. D.: The concentration and isotopic abundances of atmospheric carbon dioxide in rural areas, Geochim. Cosmochim. Ac., 13, 322-334, https://doi.org/10.1016/0016-7037(58)900334, 1958 .

Keeling, C. D.: The concentration and isotopic abundances of carbon dioxide in rural and marine air, Geochim. Cosmochim. Ac., 24, 277-298, https://doi.org/10.1016/0016-7037(61)900230,1961

Kellman, L. and Hillaire-Marcel, C.: Nitrate cycling in streams: using natural abundances of $\mathrm{NO}_{3}-\delta^{15} \mathrm{~N}$ to measure in-situ denitrification, Biogeochemistry, 43, 273-292, 1998.

Kendall, C.: Tracing Nitrogen Sources and Cycling in Catchments, chap. 16, in: Isotope Tracers in Catchment Hydrology, edited by: Kendall, C. and McDonnel, J. J., Elsevier Science B.V., Amsterdam, the Netherlands, 519-576, 1998.

Kendall, C., Elliott, E., and Wankel, S.: Tracing Anthropogenic Inputs of Nitrogen to Ecosystems, in: Stable isotopes in ecology and environmental science, edited by: Michener, R. and Lajtha, K., Blackwell, Oxford, UK, 375-449, 2007. 
Kennedy, C., Genereux, D., Corbett, D., and Mitasova, H.: Relationships among groundwater age, denitrification, and the coupled groundwater and nitrogen fluxes through a streambed, Water Resour. Res., 45, W09402, https://doi.org/10.1029/2008WR007400, 2009.

Knapp, A. N., Sigman, D. M., and Lipschultz, F.: N isotopic composition of dissolved organic nitrogen and nitrate at the Bermuda Atlantic Time-series Study site, Global Biogeochem. Cy., 19, GB1018, https://doi.org/10.1029/2004GB002320, 2005.

Kreitler, C. W., Ragone, S. E., and Katz, B. G.: N15/N14 Ratios of Ground-Water Nitrate, Long Island, New Yorka, Groundwater, 16, 404-409, 1978.

Kroopnick, P. and Craig, H.: Atmospheric oxygen: isotopic composition and solubility fractionation, Science, 175, 54-55, https://doi.org/10.1126/science.175.4017.54, 1972.

Krumholz, J. S.: Spatial and temporal patterns in nutrient standing stock and mass-balance in response to load reduction in a temperate estuary, $\mathrm{PhD}$ thesis, University of Rhode Island, Kingston, RI, USA, 401 pp., 2012.

Latimer, J. and Charpentier, M.: Nitrogen inputs to seventy-four southern New England estuaries: Application of a watershed nitrogen loading model, Estuar. Coast. Shelf Sci., 89, 125-136, 2010.

Lehmann, M. F., Sigman, D. M., McCorkle, D. C., Brunelle, B. G., Hoffmann, S., Kienast, M., Cane, G., and Clement, J.: Origin of the deep Bering Sea nitrate deficit: Constraints from the nitrogen and oxygen isotopic composition of water column nitrate and benthic nitrate fluxes, Global Biogeochem. Cy., 19, GB4005, https://doi.org/10.1029/2005GB002508, 2005.

Lin, J., Böhlke, J. K., Huang, S., Gonzalez-Meler, M., and Sturchio, N. C.: Seasonality of nitrate sources and isotopic composition in the Upper Illinois River, J. Hydrology, 568, 849-861, 2019.

Mayer, B., Boyer, E. W., Goodale, C., Jaworski, N. A., van Breemen, N., Howarth, R. W., Seitzinger, S., Billen, G., Lajtha, K., Nadelhoffer, K., Van Dam, D., Hetling, L. J., Nosal, M., and Paustian, K.: Sources of nitrate in rivers draining sixteen watersheds in the northeastern US: Isotopic constraints, Biogeochemistry, 57, 171-197, 2002.

McClelland, J. W., Valiela, I., and Michener, R. H.: Nitrogen-stable isotope signatures in estuarine food webs: A record of increasing urbanization in coastal watersheds, Limnol. Oceanogr., 42, 930937, 1997.

McMahon, P. B. and Böhlke, J. K.: Regional patterns in the isotopic composition of natural and anthropogenic nitrate in groundwater, High Plains, USA, Environ. Sci. Technol., 40, 2965-2970, https://doi.org/10.1021/es052229q, 2006.

Mengis, M., Walther, U., Bernasconi, S. M., and Wehrli, B.: Limitations of Using $\delta^{18} \mathrm{O}$ for the Source Identification of Nitrate in Agricultural Soils, Environ. Sci. Technol., 35, 1840-1844, 2001.

Michener, R. and Lajtha, K.: Stable Isotopes in Ecology and Environmental Science, Second Edition, Blackwell Publishing LTd, 2007.

Moran, S. B., Stachelhaus, S. L., Kelly, R. P., and Brush, M. J.: Submarine Groundwater Discharge as a Source of Dissolved Inorganic Nitrogen and Phosphorus to Coastal Ponds of Southern Rhode Island, Estuar. Coast., 37, 104-118, 2014.

Morford, S. L., Houlton, B. Z., and Dahlgren, R. A.: Geochemical and tectonic uplift controls on rock nitrogen inputs across terrestrial ecosystems, Global Biogeochem. Cy., 30, 333-349, 2016.
Mueller, D. K., Hamilton, P. A., Helsel, D. R., Hitt, K. J., and Ruddy, B. C.: Nutrients in ground water and surface water of the United States: An analysis of data through 1992, US Department of the Interior, US Geological Survey, Denver, Colorado, USA, 81 pp., https://doi.org/10.3133/wri954031, 1995.

Mulholland, M. R. and Lomas, M. W.: Chap. 7, Nitrogen Uptake and Assimilation, in: Nitrogen in the Marine Environment, 2nd Edn., edited by: Capone, D. G., Bronk, D. A., Mulholland, M. R., and Carpenter, E. J., Academic Press, San Diego, 303-384, 2008.

Mulholland, P. J. and Hill, W. R.: Seasonal patterns in streamwater nutrient and dissolved organic carbon concentrations: Separating catchment flow path and in-stream effects, Water Resour. Res., 33, 1297-1306, 1997.

Mulholland, P. J., Wilson, G. V., and Jardine, P. M.: Hydrogeochemical Response of a Forested Watershed to Storms: Effects of Preferential Flow Along Shallow and Deep Pathways, Water Resour. Res., 26, 3021-3036, 1990.

Murphy, J. and Riley, J. P.: A modified single solution method for the determinatino of phosphate in natural waters, Anal. Chim. Acta, 27, 31, https://doi.org/10.1016/S0003-2670(00)88444-5, 1962.

Narragansett Bay Estuary Program: State of Narragansett Bay and Its Watershed, Narragansett Bay Estuary Program, Technical Report for Narragansett Bay Estuary Program Providence, RI, USA, 166 pp., 2017.

National Atmospheric Deposition Program, NTN Data Retrieval, available at: http://nadp.slh.wisc.edu/data/NTN/ (last access: November 2019), 2019.

National Water Quality Monitoring Council: Water Quality Portal, available at: https://www.waterqualitydata.us/ (last access: November 2019), 2020.

Needoba, J., Waser, D., Harrison, P., and Calvert, S.: Nitrogen Isotope Fractionation in 12 Species of Marine Phytoplankton During Growth on Nitrate, Mar. Ecol. Progr. Ser., 255, 81-91, 2003.

Nixon, S. W., Granger, S. L., and Nowicki, B. L.: An assessment of the annual mass balance of carbon, nitrogen, and phosphorus in Narragansett Bay, Biogeochemistry, 31, 15-61, 1995.

Nixon, S. W., Buckley, B. A., Granger, S. L., Harris, L. A., Oczkowski, A. J., Fulweiler, R. W., and Cole, L. W.: Nitrogen and Phosphorus Inputs to Narragansett Bay: Past, Present, and Future, in: Science for Ecosystem-based Management, edited by: Desbonnet, A. and Costa-Pierce, B. A., Springer, New York, USA, 2008.

NOAA National Centers for Environmental information: Climate at a Glance: County Time Series, available at: https://www.ncdc. noaa.gov/cag/ (last access: 15 November 2019), 2019.

Pabich, W., Valiela, I., and Hemond, H.: Relationship between DOC concentration and vadose zone thickness and depth below water table in groundwater of Cape Cod, USA, Biogeochemistry, 55, 247-268, 2001.

Quilbé, R., Rousseau, A., Duchemin, M., Poulin, A., Gangbazo, G., and Villeneuve, J.: Selecting a Calculation Method to Estimate Sediment and Nutrient Loads in Streams: Application to the Beaurivage River (Québec, Canada), J. Hydrology, 326, 295, https://doi.org/10.1016/j.jhydrol.2005.11.008, 2006.

Rollinson, V. R., Granger, J., Clark, S. C., Blanusa, M. L., Koerting, C. P., Vaudrey, J. M. P., Treibergs, L. A., Westbrook, H. C., Matassa, C. M., Hastings, M. K., Tobias, C. 
R.: Seasonal nitrogen concentrations and nitrate isotopes of a New England River from 2018 to 2019, PANGAEA [Dataset], https://doi.org/10.1594/PANGAEA.931561, 2021.

Savarino, J. and Thiemens, M.: Analytical procedure to determine both $\delta^{18} \mathrm{O}$ and $\delta^{17} \mathrm{O}$ of $\mathrm{H}_{2} \mathrm{O}_{2}$ in natural water and first measurements, Atmos. Environ., 33, 3683-3690, 1999.

Sebestyen, S. D., Ross, D. S., Shanley, J. B., Elliott, E. M., Kendall, C., Campbell, J. L., Dail, D. B., Fernandez, I. J., Goodale, C. L., Lawrence, G. B., Lovett, G. M., McHale, P. J., Mitchell, M. J., Nelson, S. J., Shattuck, M. D., Wickman, T. R., Barnes, R. T., Bostic, J. T., Buda, A. R., Burns, D. A., Eshleman, K. N., Finlay, J. C., Nelson, D. M., Ohte, N., Pardo, L. H., Rose, L. A., Sabo, R. D., Schiff, S. L., Spoelstra, J., and Williard, K. W. J.: Unprocessed Atmospheric Nitrate in Waters of the Northern Forest Region in the US and Canada, Environ. Sci. Technol., 53, 3620-3633, 2019.

Sebilo, M., Billen, G., Grably, M., and Mariotti, A.: Isotopic composition of nitrate-nitrogen as a marker of riparian and benthic denitrification at the scale of the whole Seine River system, Biogeochemistry, 63, 35-51, 2003.

Sebilo, M., Billen, G., Mayer, B., Billiou, D., Grably, M., Garnier, J., and Mariotti, A.: Assessing Nitrification and Denitrification in the Seine River and Estuary Using Chemical and Isotopic Techniques, Ecosystems, 9, 564-577, 2006.

Seitzinger, S. and Sanders, R.: Contribution of Dissolved Organic Nitrogen From Rivers to Estuarine Eutrophication, Mar. Ecol. Progr. Ser., 159, 1-12, 1997.

Sigman, D. and Fripiat, F.: Nitrogen isotopes in the ocean, in: Encyclopedia of Ocean Sciences, edited by: Kirk, J., Cochran Henry Bokuniewicz Patricia Yager Cambridge, MA, USA, Elsevier, 263-278, https://doi.org/10.1016/B978-0-12-409548-9.11605-7, 2019.

Sigman, D., Casciotti, K., Andreani, M., Barford, C., Hastings, M., and Bohlke, J.: A Bacterial Method for the Nitrogen Isotopic Analysis of Nitrate in Seawater and Freshwater, Anal. Chem., 73, 4145-4153, 2001.

Sigman, D., Karsh, K., and Casciotti, K. L.: Nitrogen Isotopes in the Ocean, in: Encyclopedia of ocean sciences, edited by: Steele, J. H., Encyclopedia of Ocean Sciences, 2nd Edn., Amsterdam, the Netherlands, Academic Press, 40-54, 2009.

Snider, D. M., Spoelstra, J., Schiff, S. L., and Venkiteswaran, J. J.: Stable Oxygen Isotope Ratios of Nitrate Produced from Nitrification: 18O-Labeled Water Incubations of Agricultural and Temperate Forest Soils, Environ. Sci. Technol., 44, 5358-5364, 2010.

Solórzano, L. and Sharp, J. H.: Determination of total dissolved phosphorus and particulate phosphorus in natural waters, Limnol. Oceanogr., 25, 754-758, 1980.

Stevenson, F. J.: Humus Chemistry: Genesis, Composition, Reactions, 2nd edition, John Wiley and Sons, New York, USA, 1994.

Strickland, J. D. and Parsons, T. R.: A Practical Handbook of Seawater Analysis, 2nd edition, Fisheries Research Board of Canada, Ottawa, Canada, 1972.

Thiemens, M. H.: Mass-Independent Isotope Effects in Planetary Atmospheres and the Early Solar System, Science, 283, 341345, https://doi.org/10.1126/science.283.5400.341, 1999.

Tiner, R., Berquist, H., Halavik, T., and MacLachlan, A.: Eelgrass Survey for Eastern Long Island Sound, Connecticut and New York, US Fish and Wildlife Service, National Wetlands Inventory Program, Hadley, USA, 22 pp., 2003.
Townsend, M., Young, D., and Macko, S.: Kansas case study applications of nitrogen-15 natural abundance method for identification of nitrate sources, Journal of Hazardous Substance Research, 4, 22 pp., 2003.

US Census Bureau: 2017 TIGER/Line Shapefiles (Area_Water), 2019 TIGER/Line Shapefiles (machinereadable data files)/prepared by the U.S. Census Bureau, 2019, 2017.

US Environmental Protection Agency: Method 365.3: Phosphorous, All Forms (Colorimetric, Ascorbic Acid, Two Reagent), Environmental Monitoring Systems Laboratory Office of Research and Development, Environmental Monitoring Systems Laboratory Office Of Research and Development U.S. Environmental Protection Agency Cincinnati, Ohio 45268, 18 pp., 1978.

US Environmental Protection Agency: Method 350.1: Determination of Ammonia Nitrogen by semi-automated Colorimetry, Environmental Monitoring Systems Laboratory Office of Research and Development, Environmental Monitoring Systems Laboratory Office Of Research and Development U.S. Environmental Protection Agency Cincinnati, Ohio 45268, 15 pp., 1993 a.

US Environmental Protection Agency: Method 353.2: Revision 2.0: Determination of Nitrate-Nitrite Nitrogen by Automated Colorimetry, Environmental Monitoring Systems Laboratory Office of Research and Development, Environmental Monitoring Systems Laboratory Office Of Research and Development U.S. Environmental Protection Agency Cincinnati, Ohio 45268, 15 pp., $1993 b$.

US Environmental Protection Agency: Fact Sheet Spring 2005: South County RI Watersheds, SDMS Doc ID 579486, Flyer created by: United States Enivronmental Protection Agency New England, 2005.

US Environmental Protection Agency: Authorization to Discharge under the Rhode Island Pollutant Discharge Elimination System, Permit No. RI0000191, Kenyon Industries, Richmond, USA, 2010.

US Geological Survey: National Atlas of the United States for Streams and Waterbodies of the United States, available at: http: //nationalatlas.gov (last acces: September 2020), 2005.

US Geological Survey: 20140331, NLCD 2011 Land Cover, U.S. Geological Survey, Sioux Falls, SD, U.S. Geological Survey, 2011.

URIEDC_RIGIS: Watershed Boundary Dataset HUC 12, Credit: USDA-NRCS, USEPA, RI-DEM, 2019.

Valiela, I., McClelland, J., Hauxwell, J., Behr, P. J., Hersh, D., and Foreman, K.: Macroalgal blooms in shallow estuaries: controls and ecophysiological and ecosystem consequences, Limnol. Oceanogr., 42, 1105-1118, 1997.

Vaudrey, J., Yarish, C., Kim, J., Pickerell, C., Brousseau, L., Eddings, J., and Sautkulis, M.: Long Island Sound Nitrogen Loading Model, 2016.

Vaudrey, J., Brousseau, L., Yarish, C., and Kyun Kim, J.: Modeling nitrogen loads to address point and non-point source nutrient pollution, in: 24th Biennial CEFT Conference, Rhode Island, USA, November 5-9, 2017, Providence, RI, 41 pp., 2017.

Veale, N., Visser, A., Esser, B., Singleton, M., and Moran, J.: Nitrogen Cycle Dynamics Revealed Through $\delta^{18} \mathrm{O}_{-} \mathrm{NO}_{3}-$ Analysis in California Groundwater, Geosciences, 9, 95, https://doi.org/10.3390/geosciences9020095, 2019.

Wood-Pawcatuck Watershed Association: Wood-Pawcatuck Watershed Baseline Assessment, Wood-Pawcatuck Watershed Flood 
Resiliency Management Plan, Fuss and O’Neill, Manchester, USA, 2016.

Wood-Pawcatuck Watershed Association: Wood-Pawcatuck Water Quality Monitoring Data: available at: https://wpwa.org/ water-quality/ (last access: November 2019), 2020.
Xue, D., Botte, J., De Baets, B., Accoe, F., Nestler, A., Taylor, P., Van Cleemput, O., Berglund, M., and Boeckx, P.: Present limitations and future prospects of stable isotope methods for nitrate source identification in surface- and groundwater, Water Res., 43, 1159-1170, https://doi.org/10.1016/j.watres.2008.12.048, 2009.

Zhang, L., Altabet, M. A., Wu, T., and Hadas, O.: Sensitive measurement of $\mathrm{NH}_{4}{ }^{+15} \mathrm{~N} /{ }^{14} \mathrm{~N}\left(\delta^{15} \mathrm{NH}_{4}{ }^{+}\right)$at natural abundance levels in fresh and saltwaters, Anal. Chem., 79, 5297-5303, 2007. 